\title{
Hexahydropyrrolo[2,3-b]indole compounds as potential therapeutics for Alzheimer Disease
}

Deborah Doensł, Mario E. Valdés-Tresancoł, Velmarini Vasquez, Maria Beatriz Carreira, Yila De La Guardia, David E. Stephens, Viet D. Nguyen, Vu T. Nguyen, Jianhua Gu, Muralidhar Hegde, Oleg V. Larionov, Pedro A. Valiente, Ricardo Lleonart, Patricia L. Fernández*

Molecular dynamics simulations procedures. $\mathrm{Na}^{+}$and $\mathrm{Cl}^{-}$ions were added to achieve the electroneutrality of the system. The distance between the systems and the edge of the box were set to $10 \AA$. The LINCS $^{1}$ and SETTLE ${ }^{2}$ algorithms were used to constrain the covalent bonds in protein and water molecules, respectively. Before the production run, the systems were relaxed by 1000 steps using the steepest descent algorithm followed by other 1000 steps using the conjugate gradient method, where the protein heavy atoms were held fixed by a $10 \mathrm{kcal} / \mathrm{mol} \cdot \AA^{2}$ constraint. Then, the systems were gradually heated for $500 \mathrm{ps}$ to reach the experimentally reported assay temperature (310 $\mathrm{K})$. For the equilibration phase, the temperature and the pressure were controlled by using the Berendsen coupling algorithm with a time constant of 0.1 and $1.0 \mathrm{ps}$, respectively ${ }^{3}$. Newton's equation of motion was solved using the Leapfrog scheme ${ }^{4}$, with an integration time step of 2 fs. Initial velocities were randomly generated from a Maxwell distribution at $1 \mathrm{~K}$, in accordance with the atomic masses. For the production run, Langevin dynamics ${ }^{5}$ with an integration time step of a $2 \mathrm{fs}$, was employed to integrate the equations of motion. The temperature was controlled using the Langevine thermostat with a time constant of $2.0 \mathrm{ps.} \mathrm{The} \mathrm{Parrinello-Rahman} \mathrm{coupling} \mathrm{algorithm}{ }^{6}$ was used to keep the pressure constant and the friction coefficient $(\xi)$ was set to $0.5 \mathrm{ps}^{-1}$ in all systems. A cut-off radius of $1.2 \mathrm{~nm}$ was established for the calculation of both van der Waals and short-range electrostatic interactions. Long-range electrostatic interactions were handled by Particle Mesh Ewald (PME) summation ${ }^{7}$. The van der Waals interactions were modeled by the Lennard-Jones (6-12) potential ${ }^{8}$. Snapshots were saved at 10 ps intervals

Docking procedures. Gasteiger partial charges were added to the receptor and ligand atoms and rotatable bonds were defined for the ligand. All the nonpolar hydrogen atoms in both the receptor and the ligand were merged prior to docking simulations. The grid points and center of the box were defined according to the coordinate files obtained from AutoLigand. The weighting constants on Autodock4.2 scoring function were kept as default. Docking simulations were performed using the Lamarckian genetic algorithm (LGA) and the Solis \& Wets local search method. Each docking experiment was derived from 100 different runs that were set to terminate after a maximum of 250000 energy evaluations. The population size was set to 150 . See below other parameters included either on the grid parameter file (.gpf) or docking parameter file (.dpf), for all the docking convergence analysis. 
.gpf file content

npts 805454

gridfld rec.maps.fld

spacing 0.375

receptor_types A C HD N NA OA

SA

ligand_types A C HD N NA OA

receptor rec.pdbqt

gridcenter -2.8 - 1.34 .0

smooth 0.5

map rec.A.map

map rec.C.map

map rec.HD.map

map rec.N.map

map rec.NA.map

map rec.OA.map

elecmap rec.e.map

dsolvmap rec.d.map

dielectric -0.1465
\# num.grid points in xyz

\# grid_data_file

\# spacing(A)

\# receptor atom types

\# ligand atom types

\# macromolecule

\# xyz-coordinates or auto

\# store minimum energy $w /$ in $\operatorname{rad}(\mathrm{A})$

\# atom-specific affinity map

\# atom-specific affinity map

\# atom-specific affinity map

\# atom-specific affinity map

\# atom-specific affinity map

\# atom-specific affinity map

\# electrostatic potential map

\# desolvation potential map

$\#<0$, AD4 distance-dep.diel; $>0$, constant

.dpf file content

autodock_parameter_version 4.2 \# used by autodock to validate parameter set

outlev 1

\# diagnostic output level

intelec

\# calculate internal electrostatics

seed pid time

\# seeds for random generator

ligand_types A C HD N NA OA

\# atoms types in ligand

fld rec.maps.fld

\# grid_data_file 


\begin{tabular}{|c|c|}
\hline map rec.A.map & \# atom-specific affinity map \\
\hline map rec.C.map & \# atom-specific affinity map \\
\hline map rec.HD.map & \# atom-specific affinity map \\
\hline map rec.N.map & \# atom-specific affinity map \\
\hline map rec.NA.map & \# atom-specific affinity map \\
\hline map rec.OA.map & \# atom-specific affinity map \\
\hline elecmap rec.e.map & \# electrostatics map \\
\hline desolvmap rec.d.map & \# desolvation map \\
\hline move 1_RR.pdbqt & \# small molecule \\
\hline about $-1.1062-0.02930 .1387$ & \# small molecule center \\
\hline tran0 random & \# initial coordinates/A or random \\
\hline quaternion0 random & \# initial orientation \\
\hline dihe 0 random & \# initial dihedrals (relative) or random \\
\hline torsdof 4 & \# torsional degrees of freedom \\
\hline rmstol 2.0 & \# cluster_tolerance/A \\
\hline extnrg 1000.0 & \# external grid energy \\
\hline e0max 0.010000 & \# max initial energy; max number of retries \\
\hline ga_pop_size 150 & \# number of individuals in population \\
\hline ga_num_evals 2500000 & \# maximum number of energy evaluations \\
\hline ga_num_generations 27000 & \# maximum number of generations \\
\hline ga_elitism 1 & $\begin{array}{l}\text { \# number of top individuals to survive to next } \\
\text { generation }\end{array}$ \\
\hline ga_mutation_rate 0.02 & $\#$ rate of gene mutation \\
\hline ga_crossover_rate 0.8 & $\#$ rate of crossover \\
\hline ga_window_size 10 & $\#$ \\
\hline ga_cauchy_alpha 0.0 & \# Alpha parameter of Cauchy distribution \\
\hline ga_cauchy_beta 1.0 & \# Beta parameter Cauchy distribution \\
\hline set_ga & \# set the above parameters for GA or LGA \\
\hline sw_max_its 300 & \# iterations of Solis \& Wets local search \\
\hline sw_max_succ 4 & \# consecutive successes before changing rho \\
\hline sw_max_fail 4 & \# consecutive failures before changing rho \\
\hline SW_rho 1.0 & \# size of local search space to sample \\
\hline
\end{tabular}


sw_lb_rho 0.01

1s_search_freq 0.06

set_psw1

unbound_model bound

ga_run 100

analysis
\# lower bound on rho

\# probability of performing local search on individual

\# set the above pseudo-Solis \& Wets parameters

\# state of unbound ligand

\# do this many hybrid GA-LS runs

\# perform a ranked cluster analysis 


\section{Table and figures}

Table S1: Effect of the Hexahydropyrrolo[2,3-b]indole on A $\beta$ aggregation.

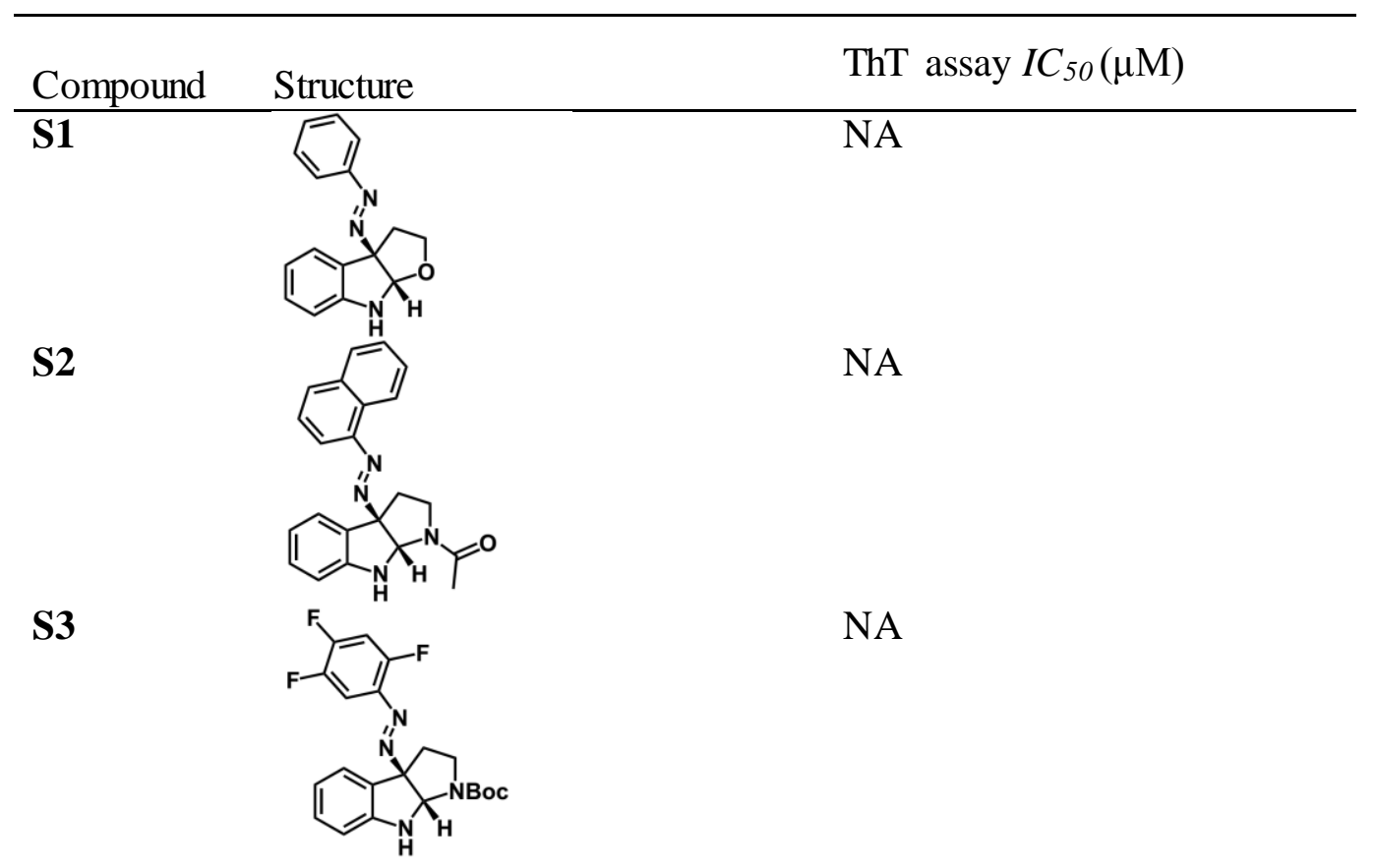

S4

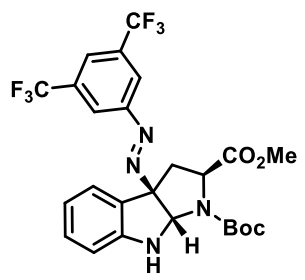

NA

S5

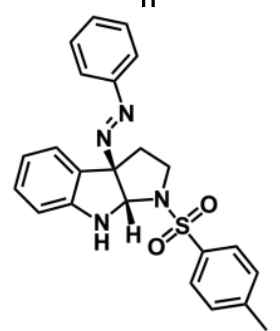

NA

S6

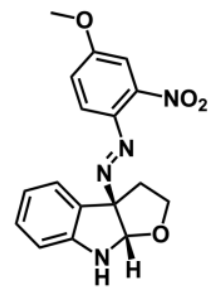

NA

S7

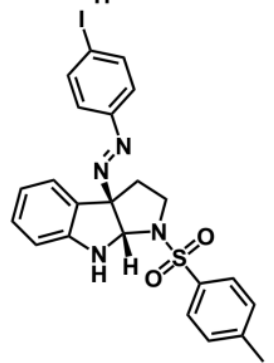

NA 
S8

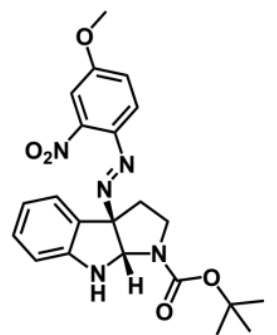

S9

S10

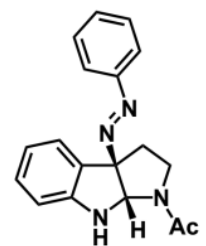

S11

S12

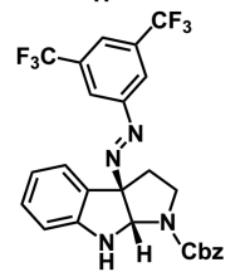

NA

NA

NA

NA

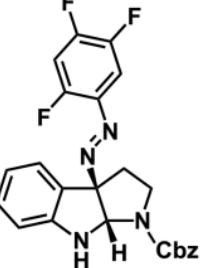

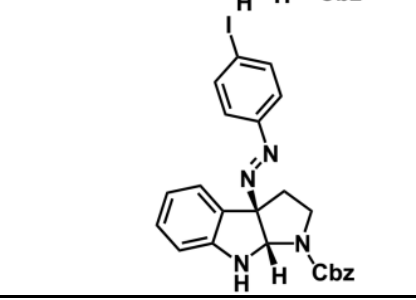

NA

9

NA, non-active

Table S2: Structural Parameters for Monomeric $A \beta_{42}$ Peptide $^{a}$

$\begin{array}{ccc}\begin{array}{c}\text { Parameters } \\ \text { total helix }\end{array} & \begin{array}{c}\text { \% } \\ \beta \text {-strand }\end{array} \\ \text { bend } & 0.03 & \begin{array}{l}\text { a } \\ \text { of } \alpha-, 3_{10^{-}}, \text {and } \pi \text {-helical content. }\end{array} \\ \text { extended } \beta \text {-strand and is olated } \beta \text {-bridge structures. } \\ \text { turn } \\ 0.03\end{array}$



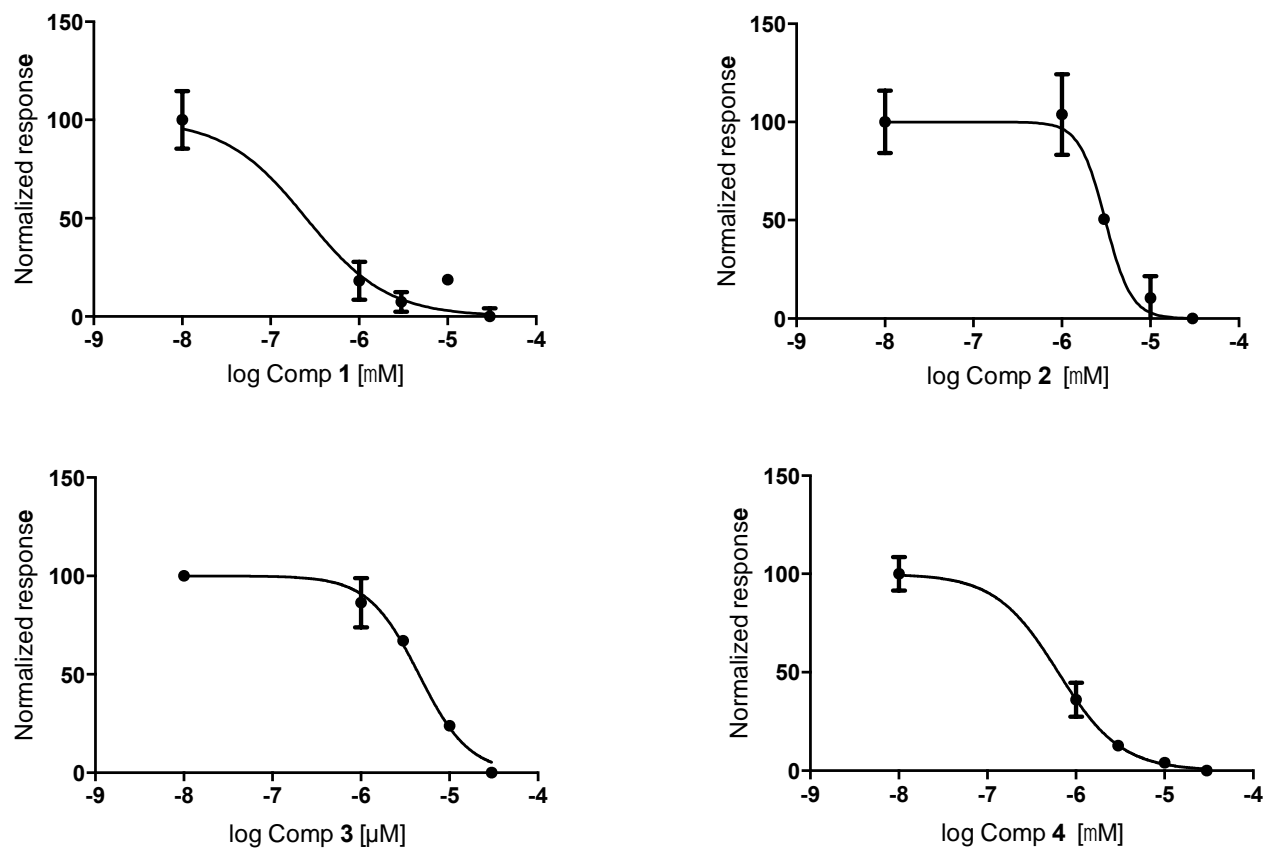

Figure S1: HPI compounds inhibit the aggregation of $\mathbf{A \beta}_{\mathbf{4 2}}$. $\mathrm{IC}_{50}$ sigmoidal curves calculated by the statistical software package GraphPad Prism 6 from active compounds shown in Table 1. Graphs represent the sigmoidal curves for the $\mathrm{IC}_{50}$ calculation of a representative experiment. Results represent means \pm S.D. from samples as sayed in triplicates. 


\section{A}

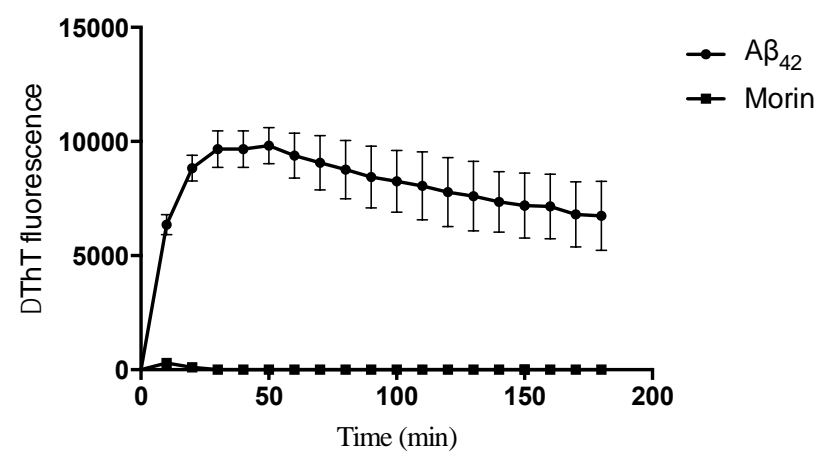

B

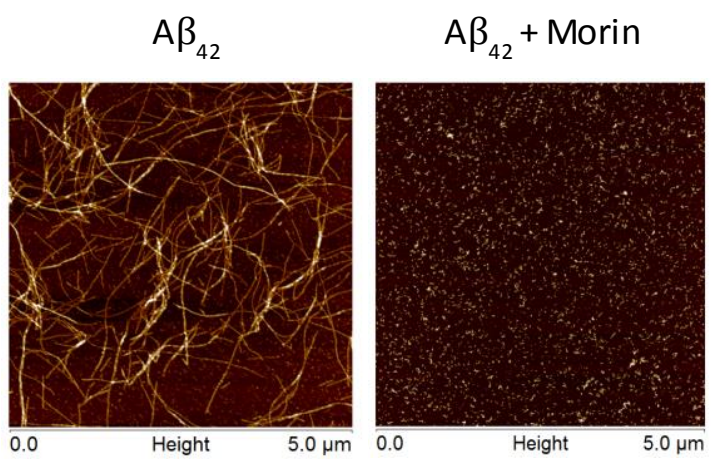

Figure S2: Morin completely abrogated the aggregation of $\mathbf{A} \boldsymbol{\beta}_{\mathbf{4 2}}$. (A) Kinetics of the effect of Morin (100 $\mu \mathrm{M})$ on the aggregation of $\mathrm{A} \beta_{42}$. ThT fluorescence was monitored every 10 minutes for a total period of 3 hours. Results as represented as mean \pm SEM from samples assayed in triplicates and are representative of two independent experiments. (B) AFM images collected after 48 hours of incubation of $A \beta_{42}$ in the absence or presence of Morin $(100 \mu \mathrm{M})$. 



Figure S3: Summary of structural changes of $\mathbf{A B}_{42(m)}$ throughout $\mathrm{MD}$ simulations. (A) Time evolution of the radius of gyration of free $A \beta_{42(m)}$. (B) Time evolution of the number of hydrophobic contacts in $A \beta_{42(m)}$. The dashed line marks the ending of the first 35 ns MD simulation (green). In both cases, results from the two additional $40 \mathrm{~ns}$ MD simulation are depicted as blue and red lines, respectively. 


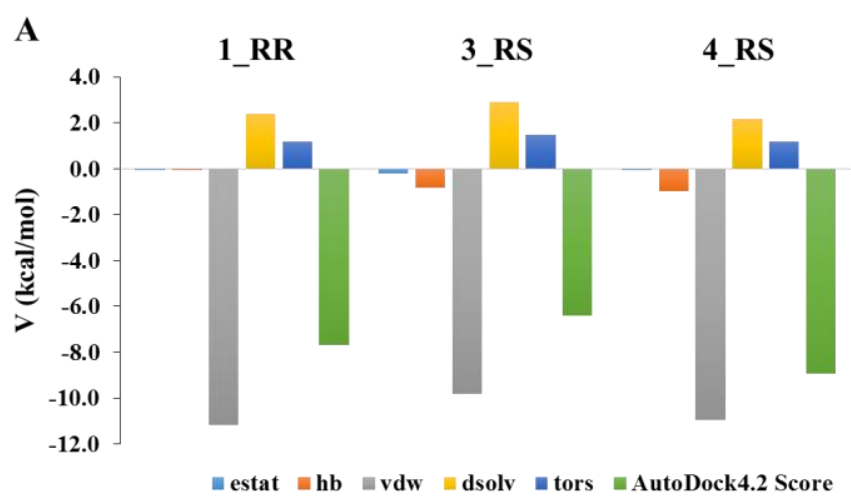

B

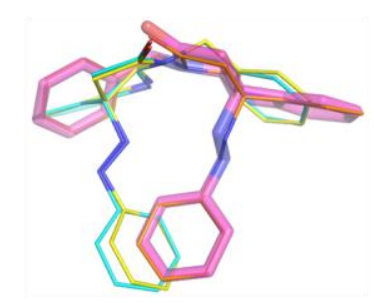

\begin{tabular}{cc|c}
\hline Conf. & MBE $^{\mathbf{a}}$ & No. poses \\
\hline $\mathrm{RR}$ & -7.6 & 95 \\
$\mathrm{RS}$ & -7.5 & 91 \\
$\mathrm{SR}$ & -6.9 & 35 \\
$\mathrm{SS}$ & -7.2 & 38 \\
\hline $\mathrm{a}$ in $\mathrm{kcal} / \mathrm{mol}$ & &
\end{tabular}

${ }^{\mathrm{a}}$ in $\mathrm{kcal} / \mathrm{mol}$
C

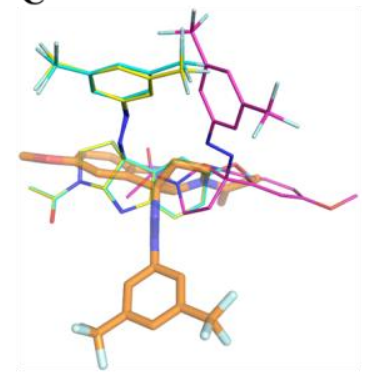

\begin{tabular}{c|cc}
\hline Conf. & MBE $^{\mathbf{a}}$ & No. poses \\
\hline RR & -6.0 & 56 \\
RS & -6.3 & 65 \\
SR & -5.6 & 28 \\
SS & -5.9 & 33 \\
\hline
\end{tabular}

${ }^{\mathrm{a}}$ in $\mathrm{kcal} / \mathrm{mol}$
D

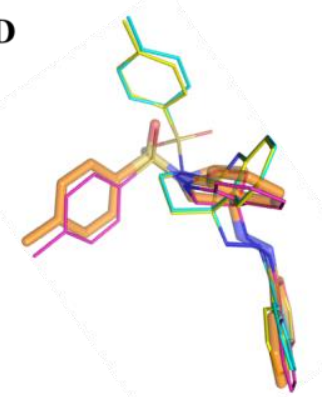

\begin{tabular}{c|c|c|}
\hline Conf. & MBE $^{\text {a }}$ & No. poses \\
\hline RR & -8.4 & 52 \\
RS & -8.4 & 57 \\
\hline SR & -8.5 & 20 \\
\hline SS & -8.5 & 26 \\
\hline
\end{tabular}

$\mathrm{a}$ in $\mathrm{kcal} / \mathrm{mol}$

Figure S4: Energetic components from AutoDock4.2 scoring function, representative poses and mean binding energies (MBE) of the most populated clusters. (A) Components from the AutoDock4.2 scoring function: electrostatic (estat; cyan), hydrogen bond (hb; orange), van der Waals (vdw; gray), desolvation (desolv; yellow), torsional (tors; blue) and AutoDock4.2 score (green). Structural superposition of the representative structures belonging to the most populated clusters (B) $\mathbf{1}$, (C) $\mathbf{3}$, and (D) $\mathbf{4}$. The configurations of the largest cluster are depicted as sticks. Poses are colored according to their configuration; RR (carbon atoms in magenta), RS (carbon atoms in orange), SR (carbon atoms in yellow), and SS (carbon atoms in cyan). Table showing the mean binding energies (MBE, in $\mathrm{kcal} / \mathrm{mol}$ ) of the selected clusters has been placed near the corresponding figure. 
A

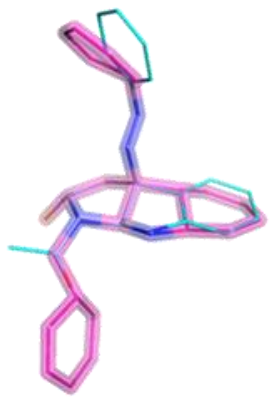

B

\begin{tabular}{|c|c|c|}
\hline Conf. & MBE $^{\text {a }}$ & No. poses \\
\hline RR & -6.8 & 47 \\
\hline RS & -6.6 & 17 \\
\hline SR & -6.7 & 26 \\
\hline SS & -6.6 & 36 \\
\hline
\end{tabular}

a in $\mathrm{kcal} / \mathrm{mol}$

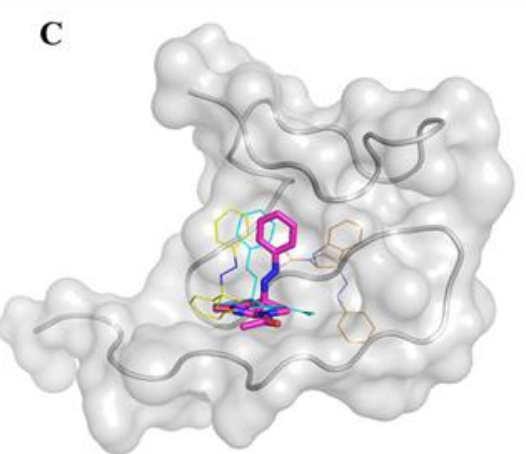

Figure S5: Modeling studies on "non-active" S9 compound. (A) Similarity analysis of compounds $\mathbf{1}$ and S9. The structural alignment was generated in MarvinSketch 17.3.13.0 (ChemAxon Ltd.). Compound $\mathbf{1}$ is highlighted as sticks (carbon in magenta, nitrogen in blue and oxygen in red) whereas Compound $\mathbf{S 9}$ is depicted as lines (carbon in cyan, nitrogen in blue and oxygen in red). (B) mean binding energies (MBE, in kcal/mol) of the most populated clusters. (C) Structural superposition of the representative structures belonging to the most populated clusters. The configuration of the largest cluster is depicted as sticks. Poses are colored according to their configuration; RR (carbon atoms in magenta), RS (carbon atoms in orange), SR (carbon atoms in yellow), and SS (carbon atoms in cyan). A $\beta_{42}$ peptide has been depicted as gray surface.

A

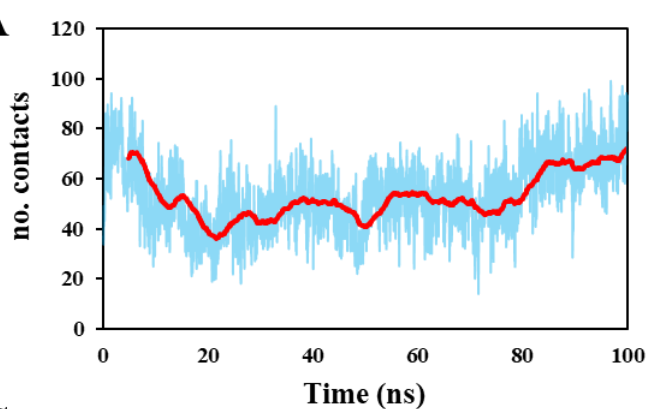

C

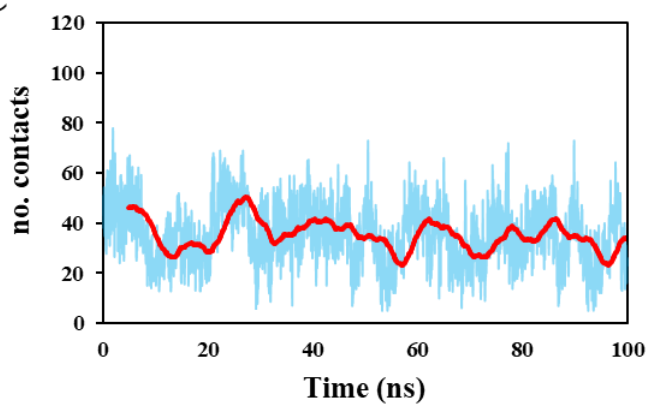

B

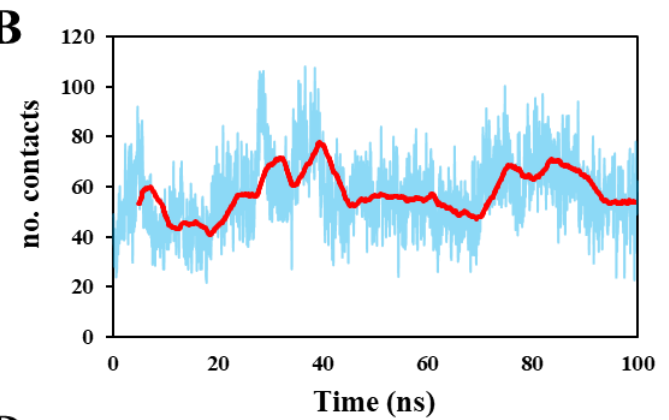

D

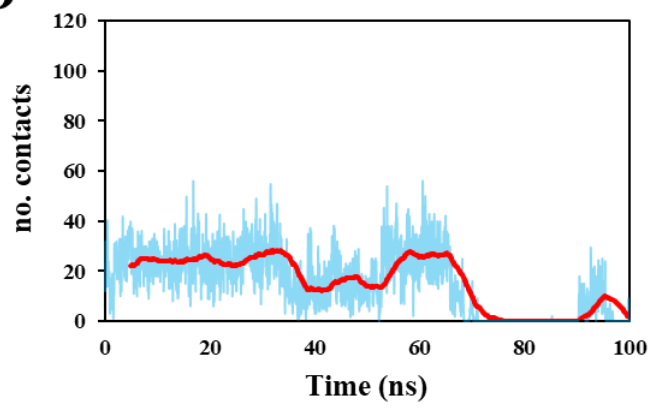

Figure S6. Time evolution of the number of contacts (no. contacts) for the predicted complexes. (A) $\mathrm{A} \beta 42$ :compound 1; (B) $\mathrm{A} \beta 42$ :compound 3; (C) $\mathrm{A} \beta 42$ :compound 4, and (D) $\mathrm{A} \beta_{42}$ :compound $\mathbf{S 9}$. The red line indicates the moving average (period $=100)$. 

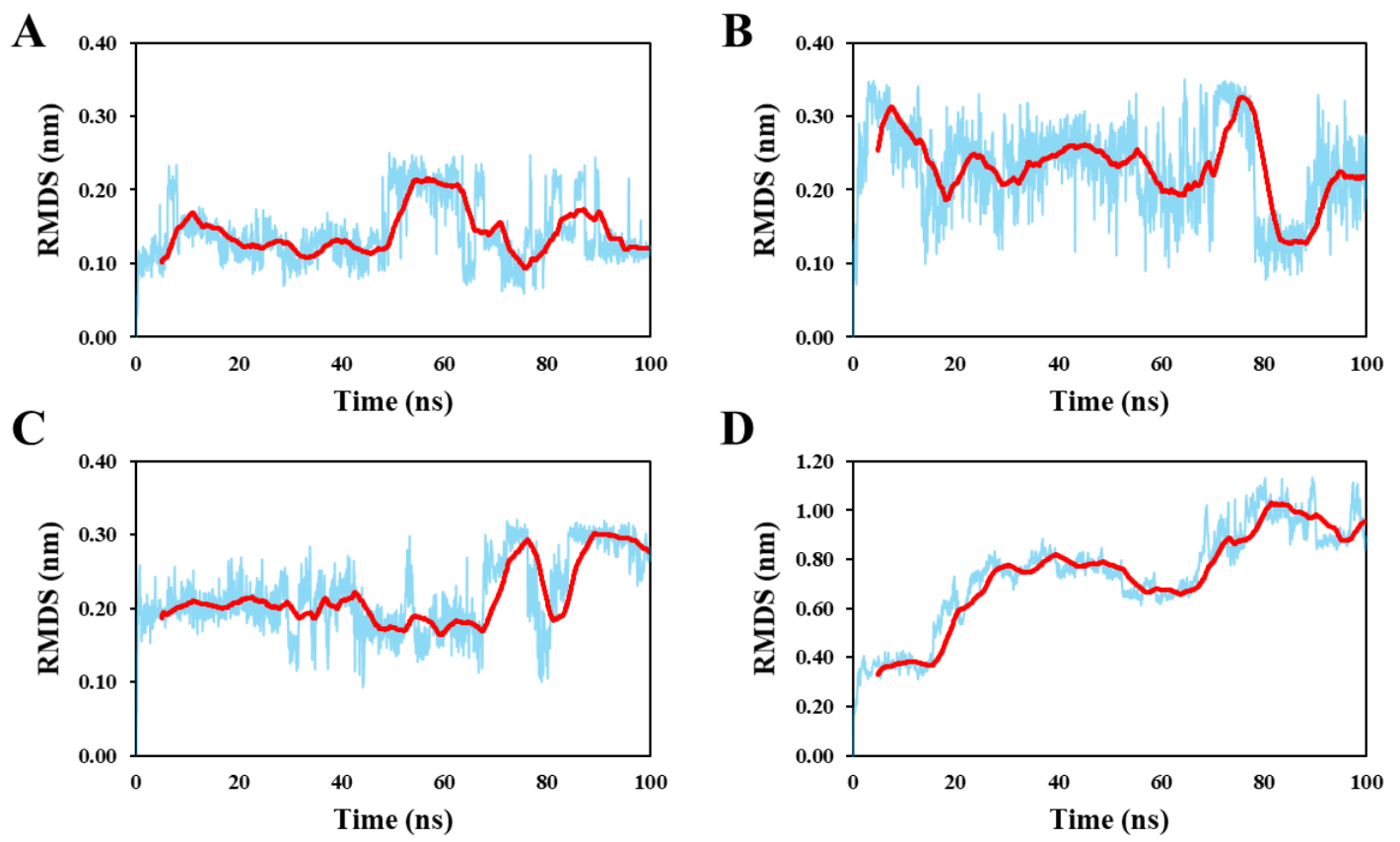

Figure S7. Time evolution of the RMSD of ligands heavy atoms. (A) compound 1; (B) compound 3; (C) compound 4, and (D) compound $\mathbf{S 9}$. The red line indicates the moving average (period $=100$ ).

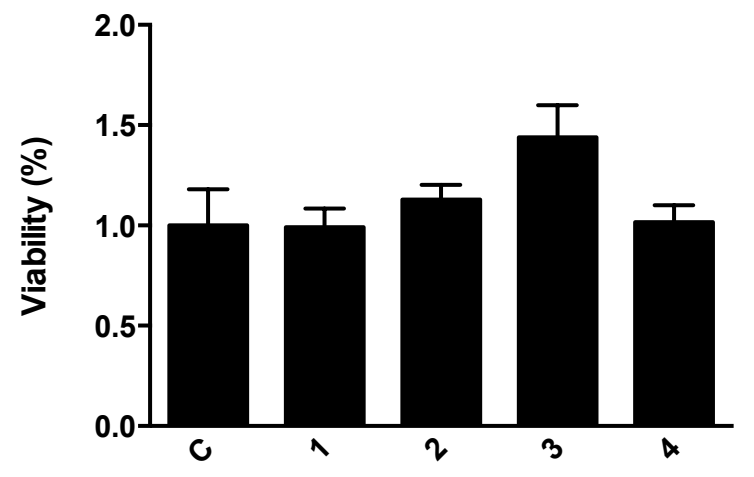

Figure S8: HPI compounds are not toxic for PC-12 cells. PC-12 cells were incubated with the compounds $(30 \mu \mathrm{M})$ for 24 hours and viability was assayed by MTT method. Data is normalized to negative control. Results represent mean \pm SEM from two experiments performed in triplicate. 

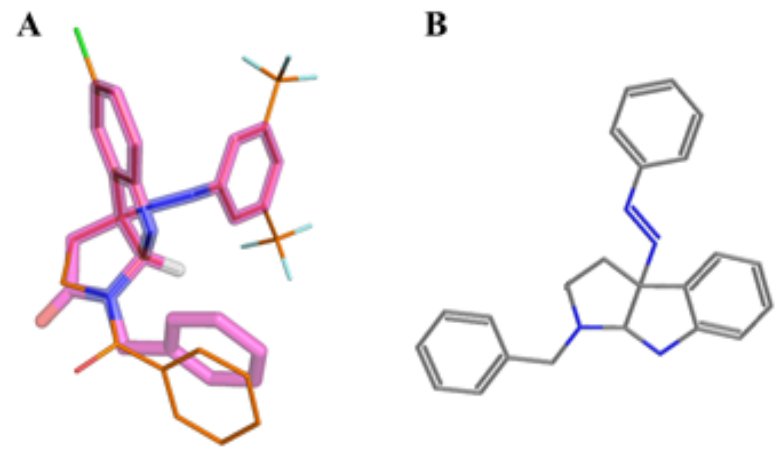

Figure S9: Similarity analysis of compounds 1 and 2. (A) The structural alignment was generated in MarvinSketch 17.3.13.0 (ChemAxon Ltd.). Compound $\mathbf{1}$ is highlighted as sticks (carbon in magenta, nitrogen in blue and oxygen in red) whereas Compound $\mathbf{2}$ is depicted as lines (carbon in orange, chlorine in green, fluorine in cyan, nitrogen in blue and oxygen in red). (B) Common scaffold generated in OSIRIS DataWarrior version 4.5.2 (Actelion Pharmaceuticals Ltd.)

A

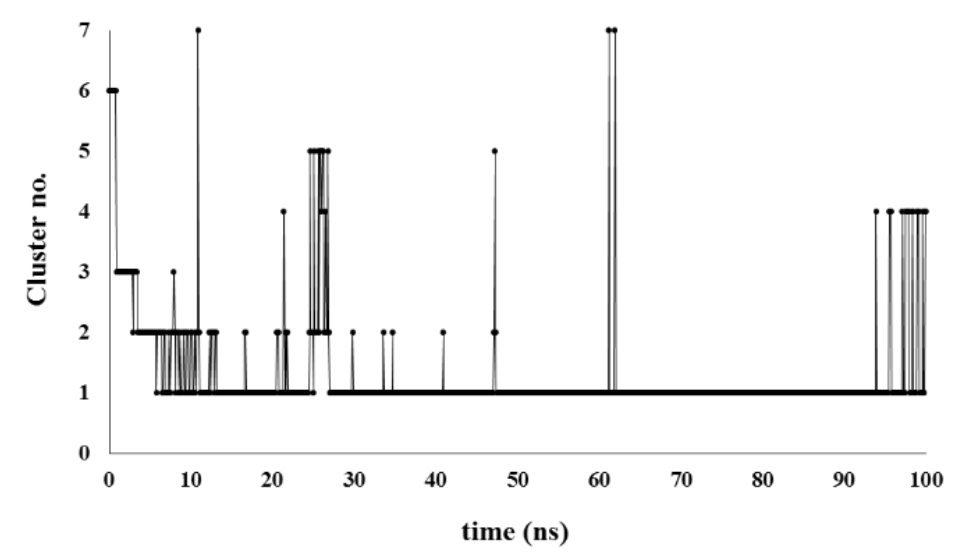

B

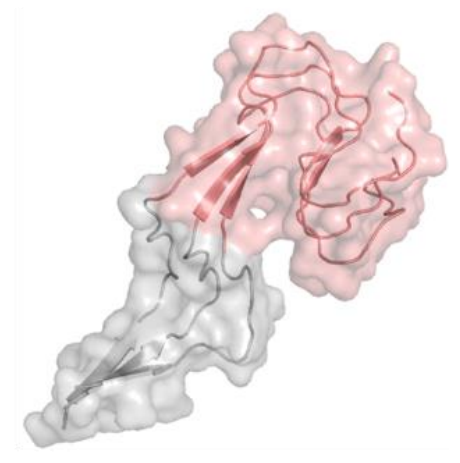

Figure S10: Analysis of $\mathbf{A \beta}_{\mathbf{4}}$ structures generated from $100 \mathrm{~ns}$ MD simulation. (A) Cluster transition plot for $\mathrm{A} \beta_{42}$ conformers. (B) The central structure of the most populated cluster (cluster no.1). The peptide is shown as cartoon to illustrate the secondary structure. The overlaid transparent surface is shown to give an impression of the overall shape of the fibril. N-terminal segment (residues 1-14) is highlighted with gray color, the doublehorseshoe structure comprising residues 15-42 is highlighted with salmon color. 


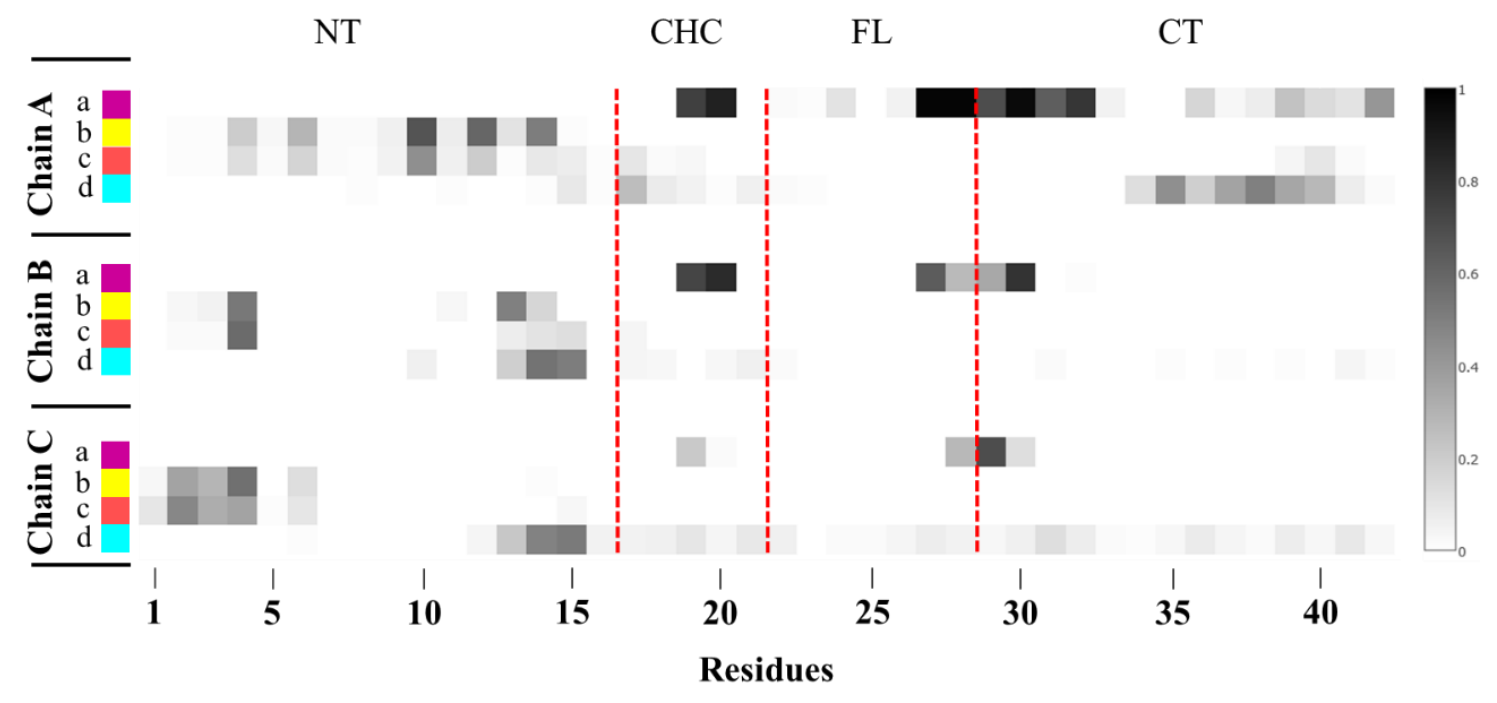

Figure S11: Contact map between the heavy atoms of compound 1 molecules and A $\beta_{42}$ residues. Interactions with chain $\mathrm{A}, \mathrm{B}$, and $\mathrm{C}$ of $\mathrm{A} \beta_{42}$ are shown for each one of the compound $\mathbf{1}$ molecules: $\mathbf{1 a}$ (magenta in figure 2), $\mathbf{1 b}$ (yellow in figure 2), $\mathbf{1 c}$ (salmon in figure 2) and $\mathbf{1 d}$ (cyan in figure 2). The color gradient from white to black is indicative of an increase in contact frequency. The red dashed lines label the four regions of $\mathrm{A} \beta_{42}$ : N-Terminal (NT), Central Hydrophobic Core (CHC), Fibril-Loop (FL) and C-Terminal (CT). 

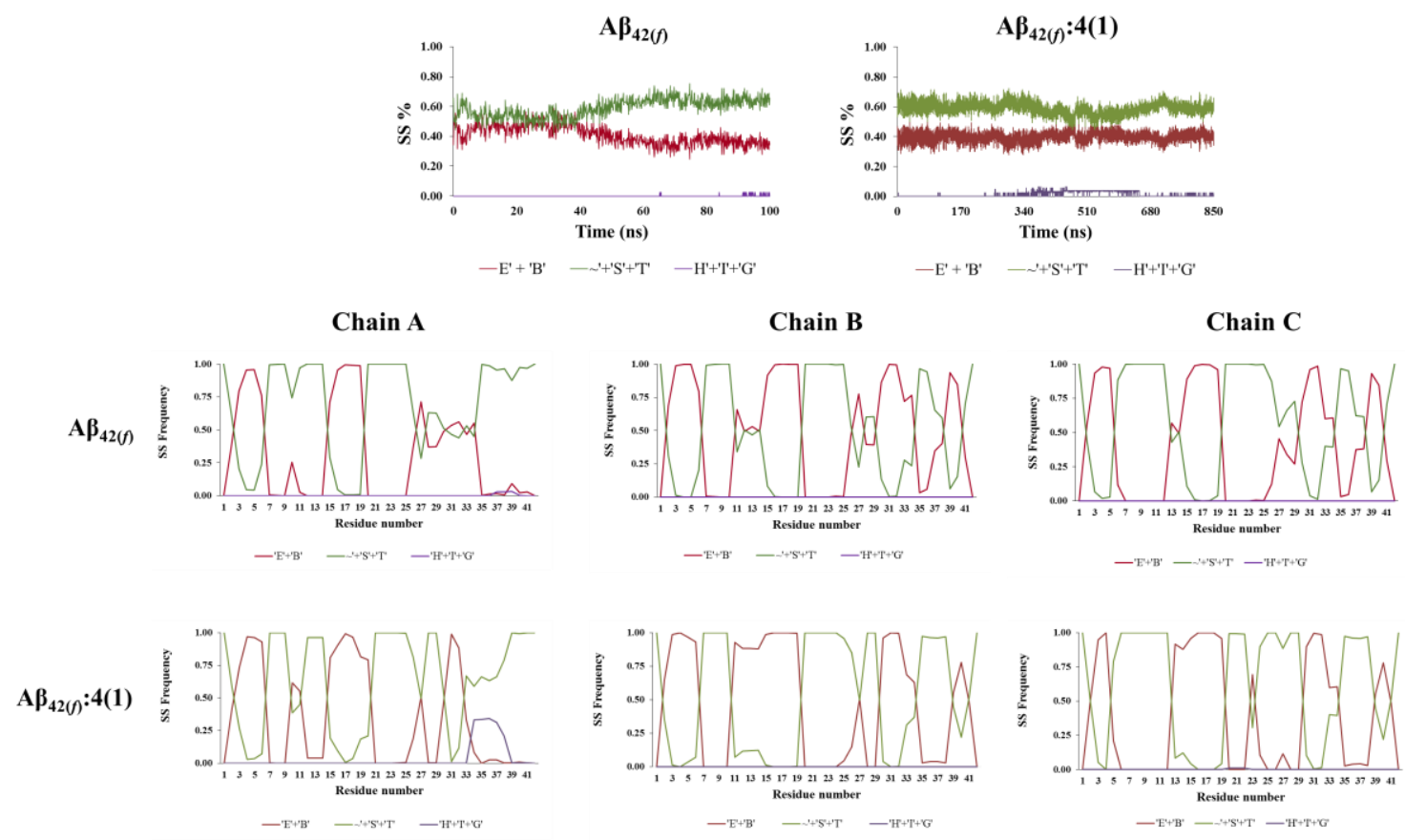

Figure S12: Secondary structure profile of free $A \beta_{42}$ fibril $\left(A \beta_{42(f)}\right)$ and in complex with four molecules of compound $1\left[\mathbf{A} \boldsymbol{\beta}_{\mathbf{4 2}(f)}: 4(\mathbf{1})\right]$. The content of different secondary structures during MD simulations are shown in graphs placed at the upper panel. Per-residue frequencies of different secondary structures are shown in graph placed at the bottom panel. Per-residue frequencies of different secondary structures are presented by chains for clarity. In all cases, secondary structures are grouped in the following manner for clarity: 'E' + 'B' (red) for $\beta$ sheet and $\beta$-bridges; ' ${ }^{\prime}+'{ }^{\prime}+1 ' T$ ' (green) for coil, bend and turn elements; 'H'+'I'+'G' (magenta) for $\alpha-, 3_{10}$, and $\pi$ helix. 

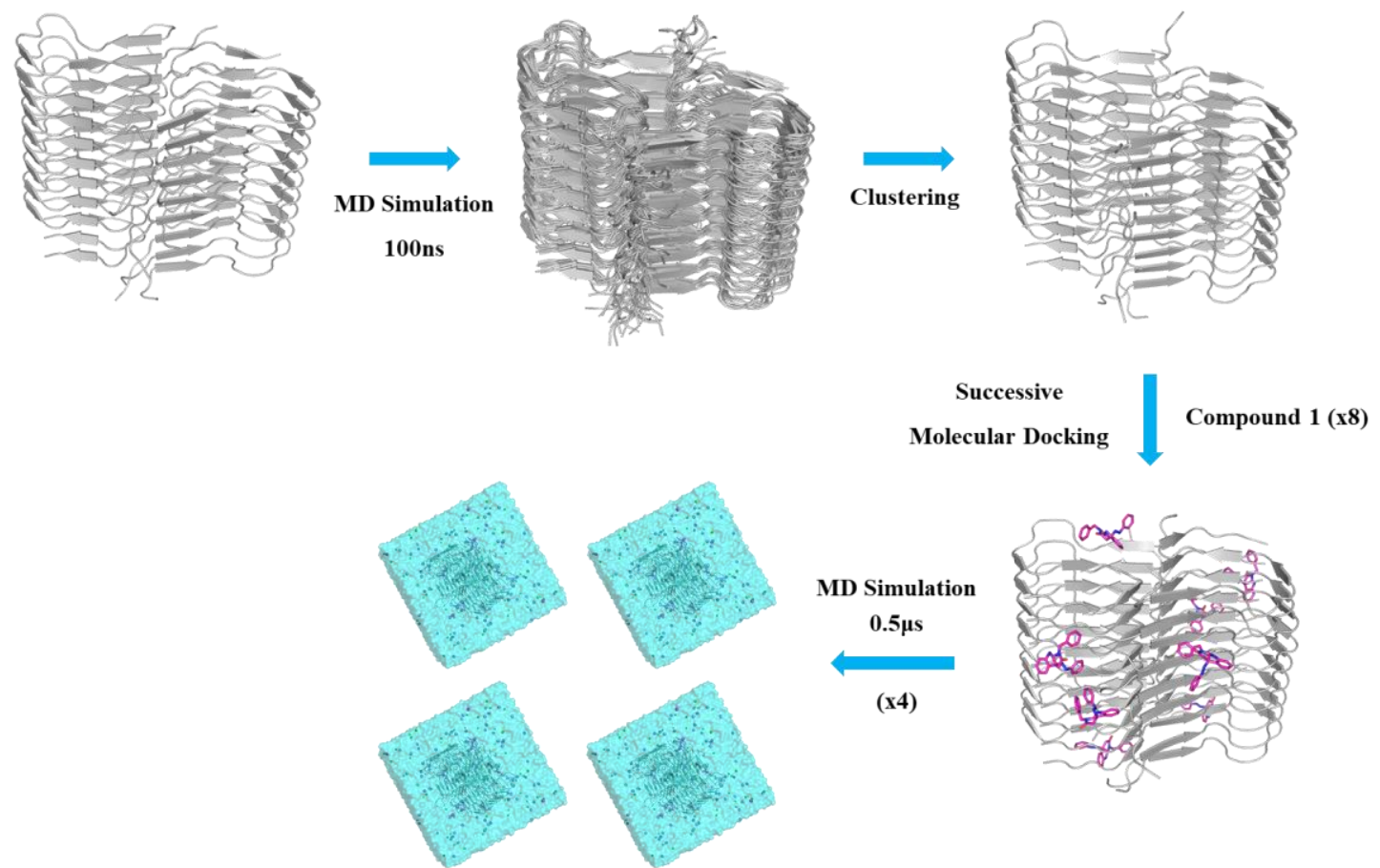

Figure S13. Procedure for studying in silico the disaggregating activity of compound 1 in a more complex system. For studying the disaggregating activity of compound $\mathbf{1}$ in this system we combined MD simulations with molecular docking as described previously. We performed MD simulations of $A \beta_{42}$ which allowed a more detailed analysis of protein conformational sampling. Cluster analysis was used to group MD conformers. Successive molecular docking enabled a quick prediction of $\mathrm{A} \beta_{42}$ structure binding eight compound 1 molecules. Lastly, four 500ns MD simulations were performed in order to assess the effect of compound 1 onto the structure and dynamics of $A \beta_{42}$ fibril.
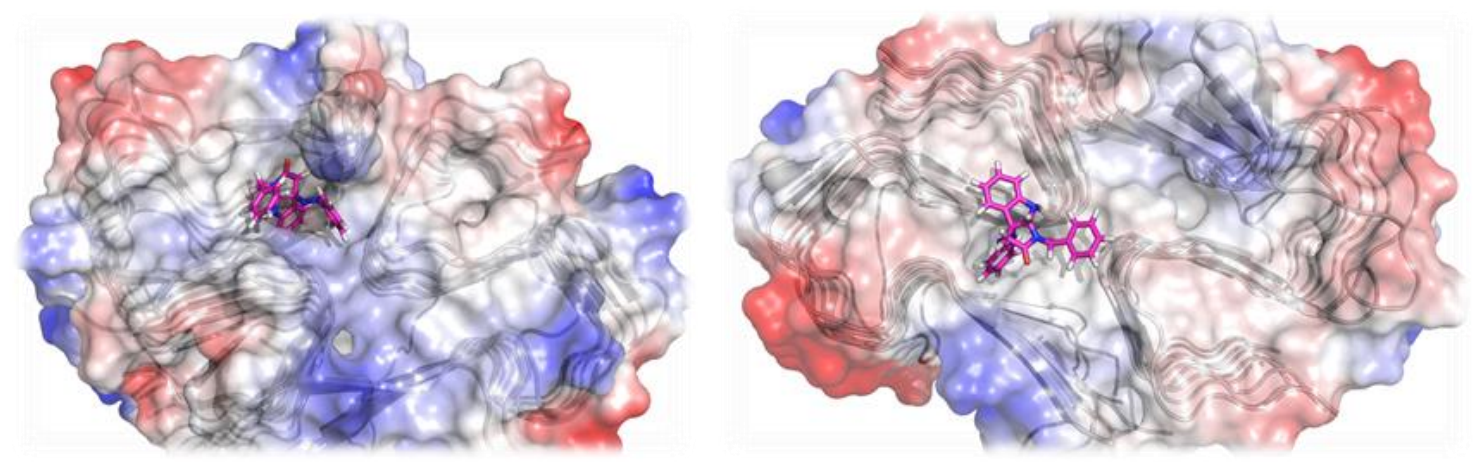

Figure S14. Snapshots from MD simulations reveal a partial insertion of compound 1 into the hydrophobic core of $\mathbf{A} \boldsymbol{\beta}_{\mathbf{4 2}}$. The electrostatic surface potential of $A \beta_{42}$ fibril is represented as a transparent surface. Compound 1 has been highlighted as sticks with $\mathrm{O}, \mathrm{N}, \mathrm{H}$, and $\mathrm{C}$ atoms colored as red, blue, white, and magenta respectively. 


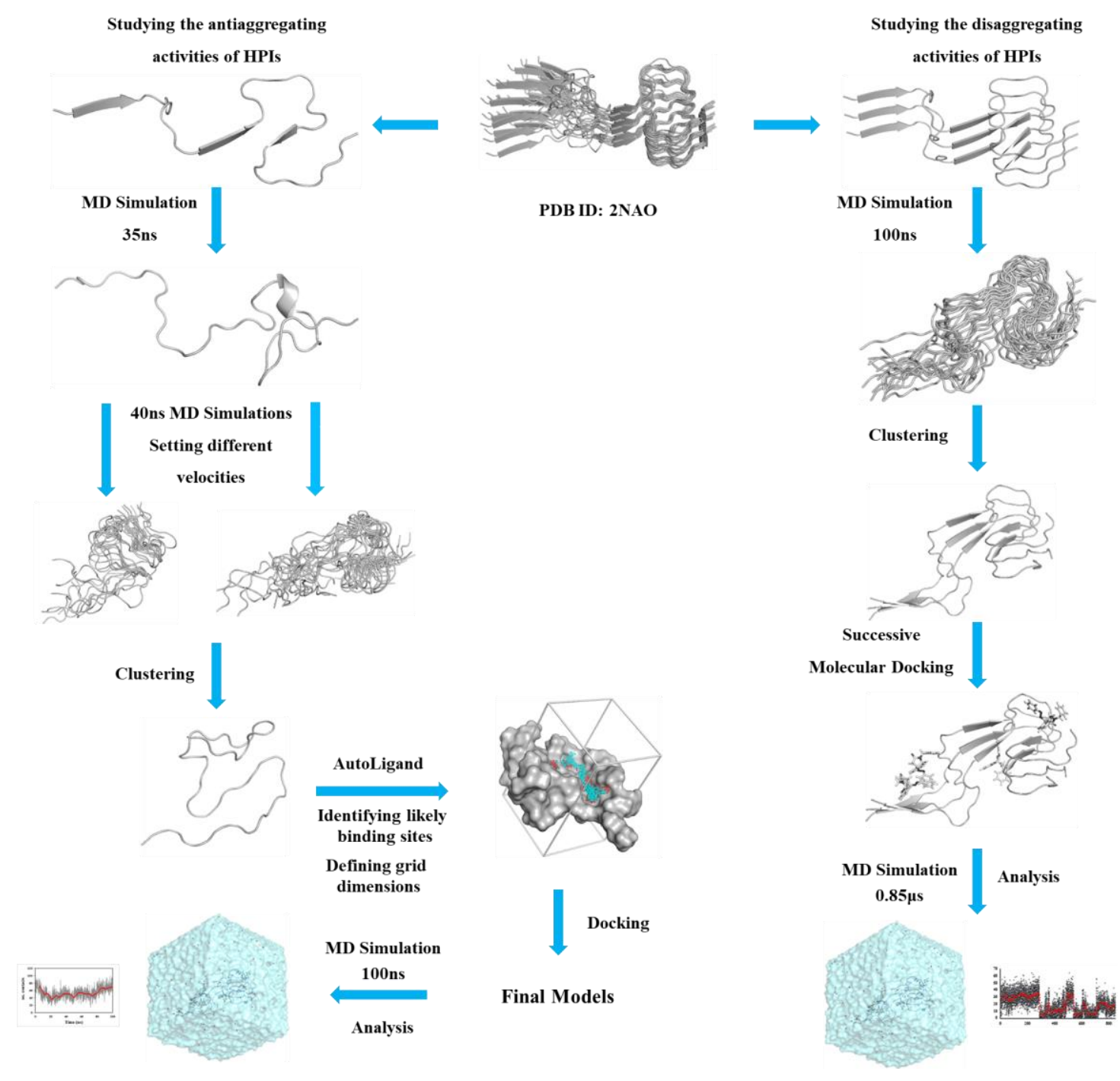

Figure S15: Procedure for studying in silico the anti-aggregating and disaggregating activities of HPIs. For studying the anti-aggregating activities of HPIs we combined MD simulations with molecular docking. A $35 \mathrm{~ns}$ MD simulation was used to relax the starting structure of $\mathrm{A} \beta_{42}(\mathrm{~m})$. Two additional MD simulations (starting with different velocities) were performed to generate an ensemble of configurations. Cluster analysis was used to group conformers. AutoLigand was used to guess putative ligand-binding regions on the target surface. Then, molecular docking was employed to predict the bound conformation and binding free energy of small molecules to the target. Finally, 100ns MD simulations were performed in order to assess the stability of the predicted complexes. On the other hand, a similar approach was used to study the disaggregating activities of HPIs. We performed MD simulation of $A \beta_{42}(f)$ which allowed a more detailed analysis of protein conformational sampling. Cluster analysis was used to group MD conformers. Successive molecular docking enabled a quick prediction of $\mathrm{A} \beta_{42}(\mathrm{f})$ structure binding four compound 1 molecules. Lastly, a $0.85 \mu \mathrm{s}$ MD simulation was performed for unraveling the effect of compound $\mathbf{1}$ onto the structure and dynamics of $A \beta_{42}$ fibril. 


\section{Compound 1}

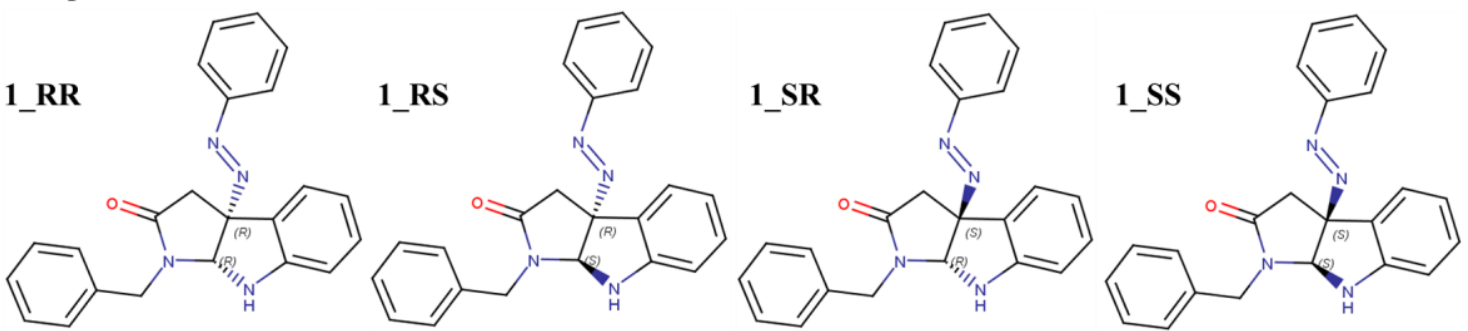

(3aR,8aR)-1-benzyl-3a-(2phenyldiazen-1-yl)-1H,2H,

$3 \mathrm{H}, 3 \mathrm{aH}, 8 \mathrm{H}, 8 \mathrm{aH}$-pyrrolo

[2,3-b]indol-2-one
(3aR,8aS)-1-benzyl-3a-(2phenyldiazen-1-yl)-1H,2H

$3 \mathrm{H}, 3 \mathrm{aH}, 8 \mathrm{H}, 8 \mathrm{aH}-$ pyrrolo

[2,3-b]indol-2-one
(3aS,8aR)-1-benzyl-3a-(2phenyldiazen-1-yl)-1H,2H

$3 \mathrm{H}, 3 \mathrm{aH}, 8 \mathrm{H}, 8 \mathrm{aH}-$ pyrrolo

[2,3-b]indol-2-one
(3aS,8aS)-1-benzyl-3a-(2 phenyldiazen-1-yl)-1 H,2 $\mathrm{H}$ $3 \mathrm{H}, 3 \mathrm{aH}, 8 \mathrm{H}, 8 \mathrm{aH}-$ pyrrolo [2,3-b]indol-2-one

\section{Compound 2}

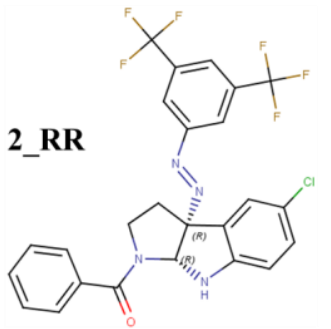

(3aR,8aR)-1-benzoyl3a- $\{2-[3,5-b i s$ (trifluoro methyl)phenyl]diazen-1 yl \}-5-chloro-1H,2H,

$3 \mathrm{H}, 3 \mathrm{aH}, 8 \mathrm{H}, 8 \mathrm{aH}-$

pyrrolo[2,3-b]indole

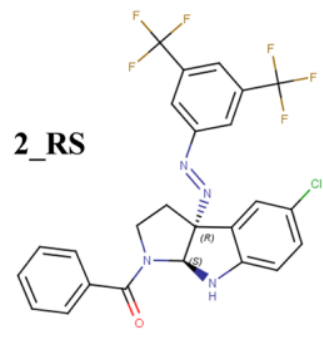

(3aR,8aS)-1-benzoyl3a- $\{2-[3,5-b i s$ (trifluoro methyl)phenyl]diazen-1 yl \}-5-chloro- $1 \mathrm{H}, 2 \mathrm{H}$ $3 \mathrm{H}, 3 \mathrm{aH}, 8 \mathrm{H}, 8 \mathrm{aH}-$ pyrrolo[2,3-b]indole

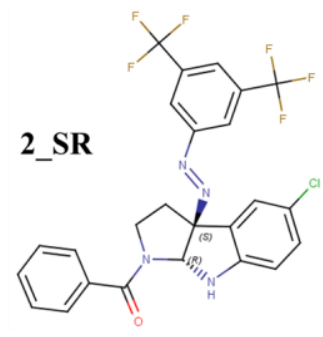

(3aS,8aR)-1-benzoyl$3 a-\{2-[3,5$-bis(trifluoro methyl)phenyl]diazen-1yl $\}$-5-chloro- $1 \mathrm{H}, 2 \mathrm{H}$ $3 \mathrm{H}, 3 \mathrm{aH}, 8 \mathrm{H}, 8 \mathrm{aH}-$ pyrrolo[2,3-b]indole

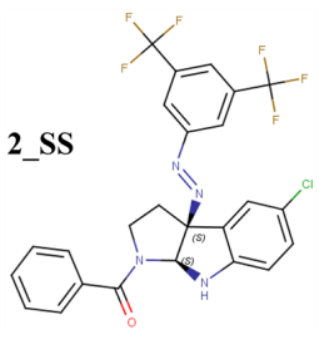

(3aS,8aS)-1-benzoyl3a- $\{2-[3,5-b i s(t r i f l u o r o$ methyl)phenyl]diazen-1yl) -5-chloro- $1 \mathrm{H}, 2 \mathrm{H}$, $3 \mathrm{H}, 3 \mathrm{aH}, 8 \mathrm{H}, 8 \mathrm{aH}-$ pyrrolo[2,3-b]indole

\section{Compound 3}

3_RR

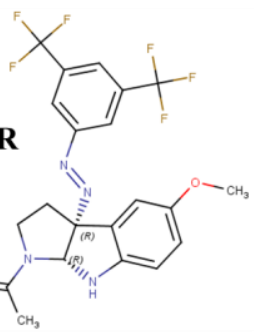

$1-[(3 a R, 8 a R)-3 a-\{2-[3$, 5-bis(trifluoromethyl) phenyl]diazen-1-yl\}-5methoxy- $1 \mathrm{H}, 2 \mathrm{H}, 3 \mathrm{H}$, $3 \mathrm{aH}, 8 \mathrm{H}, 8 \mathrm{aH}-$ pyrrolo [2,3-b]indol-1-yl]ethan -1-one
3 RS

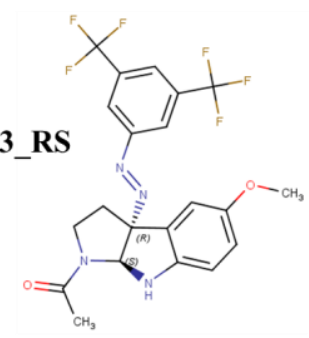

$1-[(3 \mathrm{aR}, 8 \mathrm{aS})-3 \mathrm{a}-\{2-[3$, 5-bis(trifluoromethyl) phenyl]diazen-1-yl\}-5methoxy- $1 \mathrm{H}, 2 \mathrm{H}, 3 \mathrm{H}$, $3 \mathrm{aH}, 8 \mathrm{H}, 8 \mathrm{aH}-$ pyrrolo [2,3-b]indol-1-yl]ethan -1 -one
3_SR

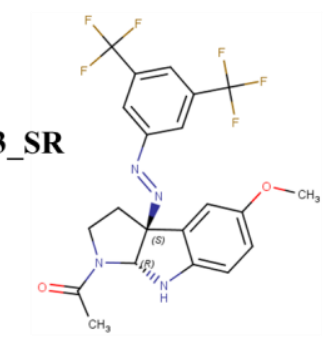

$1-[(3 \mathrm{aS}, 8 \mathrm{aR})-3 \mathrm{a}-\{2-[3$, 5-bis(trifluoromethyl) phenyl]diazen-1-yl $\}-5$ methoxy- $1 \mathrm{H}, 2 \mathrm{H}, 3 \mathrm{H}$, $3 \mathrm{aH}, 8 \mathrm{H}, 8 \mathrm{aH}-$ pyrrolo

[2,3-b]indol-1-yl]ethan -1-one
3_SS

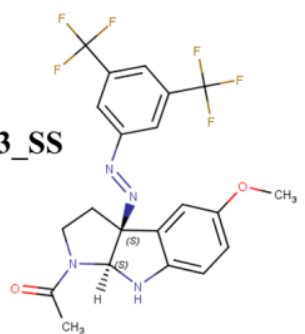

1-[(3aS, $8 \mathrm{aS})-3 \mathrm{a}-\{2-[3$, 5-bis(trifluoromethyl) phenyl]diazen-1-yl\}-5methoxy- $1 \mathrm{H}, 2 \mathrm{H}, 3 \mathrm{H}$, $3 \mathrm{aH}, 8 \mathrm{H}, 8 \mathrm{aH}-$ pyrrolo [2,3-b]indol-1-yl]ethan -1-one 


\section{Compound 4}

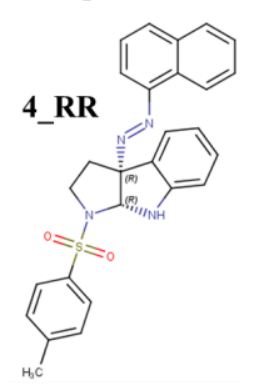

[(3aR,8aR)-1-(4-methyl benzenesulfonyl)-1 $\mathrm{H}, 2 \mathrm{H}$, $3 \mathrm{H}, 3 \mathrm{aH}, 8 \mathrm{H}, 8 \mathrm{aH}-$ pyrrolo [2,3-b]indol-3a-yl] (naphthalen-1-yl)diazene

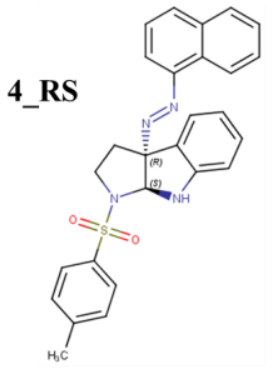

[(3aR,8aS)-1-(4-methyl benzenesulfonyl)-1 $\mathrm{H}, 2 \mathrm{H}$, $3 \mathrm{H}, 3 \mathrm{aH}, 8 \mathrm{H}, 8 \mathrm{aH}-$ pyrrolo [2,3-b]indol-3a-yl] (naphthalen-1-yl)diazene

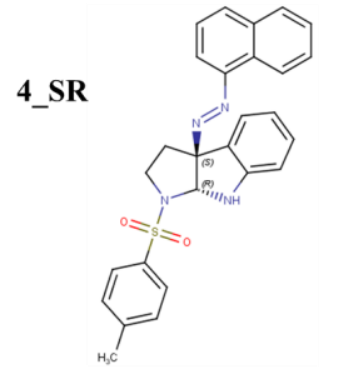

[(3aS,8aR)-1-(4-methyl benzenesulfonyl)-1 $\mathrm{H}, 2 \mathrm{H}$, $3 \mathrm{H}, 3 \mathrm{aH}, 8 \mathrm{H}, 8 \mathrm{aH}$-pyrrolo [2,3-b]indol-3a-yl] (naphthalen-1-yl)diazene

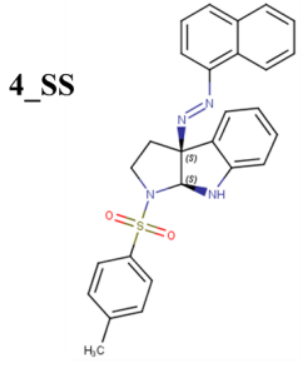

[(3aS,8aS)-1-(4-methyl benzenesulfonyl)-1 $\mathrm{H}, 2 \mathrm{H}$, $3 \mathrm{H}, 3 \mathrm{aH}, 8 \mathrm{H}, 8 \mathrm{aH}-$ pyrrolo [2,3-b]indol-3a-yl] (naphthalen-1-yl)diazene

Figure S16: 2D structures, ligand ID and IUPAC name of the selected compounds. Each one of the selected ligands has two chiral centers, so we generated four $\left(2^{2}\right)$ enantiomers. 


\section{Compound Characterization}

$\left(3 \mathrm{a} R^{*}, 8 \mathrm{a} S *\right)-3 \mathrm{a}-((E)$-Phenyldiazenyl)-3,3a,8,8a-tetrahy dro-2H-furo[2,3-b]indole (S1)

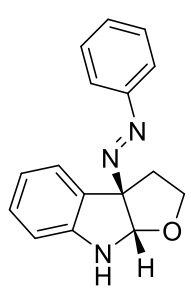

Yellow oil. $-{ }^{1} \mathrm{H}$ NMR (500 MHz, $\left.\mathrm{C}_{6} \mathrm{D}_{6}\right): 7.73(2 \mathrm{H}, \mathrm{d}, J=7.1 \mathrm{~Hz}), 7.23(1 \mathrm{H}$, $\mathrm{dd}, J=7.5,1.2 \mathrm{~Hz}), 7.12-6.98(4 \mathrm{H}, \mathrm{m}), 6.73(1 \mathrm{H}, \mathrm{t}, J=7.4 \mathrm{~Hz}), 6.34$ (1 H, d, $J$ $=7.9 \mathrm{~Hz}), 6.24(1 \mathrm{H}, \mathrm{d}, J=2.5 \mathrm{~Hz}), 4.04(1 \mathrm{H}, \mathrm{s}), 3.88(1 \mathrm{H}, \mathrm{ddd}, J=8.9,7.5$, $1.4 \mathrm{~Hz}), 3.69(1 \mathrm{H}$, ddd, $J=11.5,8.7,4.9 \mathrm{~Hz}), 2.60(1 \mathrm{H}, \mathrm{td}, J=11.8,7.6 \mathrm{~Hz})$, $2.21(1 \mathrm{H}$, ddd, $J=12.2,4.9,1.4 \mathrm{~Hz}) \mathrm{ppm} .-{ }^{13} \mathrm{C} \mathrm{NMR}\left(125 \mathrm{MHz}, \mathrm{C}_{6} \mathrm{D}_{6}\right): 152.5$, 151.1, 130.9, 129.9, 129.2, 125.7, 122.9, 119.2, 109.0, 96.9, 92.0, 67.2, 39.0 ppm. - IR: 3349, $3054,2947,2870,1608,1483,1470,1453,1436,1359,1333,1317,1259,1152,1042 \mathrm{~cm}^{-1}$. HRMS calcd for $\mathrm{C}_{16} \mathrm{H}_{15} \mathrm{~N}_{3} \mathrm{ONa}$ : 288.1107, found [M+Na ${ }^{+}$288.1105.

\section{1-((3a $\left.R^{*}, 8 \mathrm{a} S *\right)-3 \mathrm{a}-((E)-N a p h t h a l e n-1-y$ ldiazenyl)-3,3a,8,8a-tetrahydropy r rolo[2,3- b]indol-1(2H)-yl)ethan-1-one (S2)}

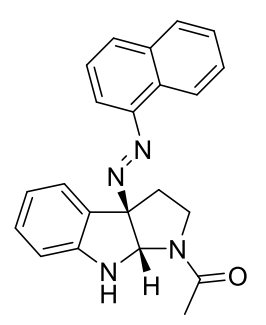

Orange oil. $-{ }^{1} \mathrm{H}$ NMR (500 MHz, $\mathrm{CD}_{3} \mathrm{CN}$, rotamers): 8.68-8.58 (1 H, m), 8.07-7.93 (2 H, m), 7.70-7.58 (2 H, m), 7.58-7.50 (1 H, m), 7.50-7.43 (1 H, m), 7.39-7.31 (1 H, m), 7.24-7.12 (1 H, m), 6.90-6.69 (2 H, m), 6.28-6.04 (1 H, m), 5.76-5.61 (1 H, m), 4.13-3.77 (1 H, m), 3.46-3.04 (1 H, m), 2.84$2.59(2 \mathrm{H}, \mathrm{m}), 2.25-2.01(3 \mathrm{H}, \mathrm{m}) \mathrm{ppm} .-{ }^{13} \mathrm{C} \mathrm{NMR}\left(125 \mathrm{MHz}, \mathrm{CD}_{3} \mathrm{CN}\right.$, rotamers): $170.0,169.2,151.0,150.7,146.9,134.2,131.1,131.1,130.1,130.1,130.1,128.0$, $127.9,127.5,127.1,126.72,126.68,126.5,125.7,125.2,125.1,122.74,122.68,119.4,118.6$, $112.04,111.98,110.2,109.6,92.2,89.5,78.6,77.9,46.8,44.2,34.1,34.0,21.6,21.5$ ppm. IR: 3321, 3052, 2945, 2875, 1626, 1607, 1505, 1487, 1439, 1417, 1346, 1316, 1258, 1200, $1167,1082 \mathrm{~cm}^{-1}$. - HRMS calcd for $\mathrm{C}_{22} \mathrm{H}_{21} \mathrm{~N}_{4} \mathrm{O}: 357.1710$, found $\left[\mathrm{M}+\mathrm{H}^{+}\right] 357.1702$.

\section{tert-Butyl (3a $\left.R *, 8 a S^{*}\right)-3 a-((E)-(2,4,5$-trifluorophenyl)diazenyl)-3,3a,8,8a-}

\section{tetrahydropy rrolo $[2,3-b]$ indole-1 $(2 H)$-carboxylate $(\mathrm{S3})$}

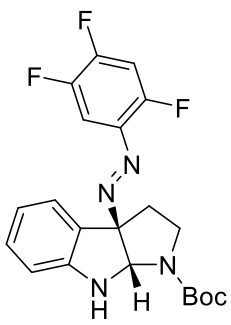

Yellow oil. $-{ }^{1} \mathrm{H}$ NMR (500 MHz, $\mathrm{CD}_{3} \mathrm{CN}$, rotamers): 7.52-7.40 (1 H, m), $7.34(1 \mathrm{H}, \mathrm{td}, J=10.3,6.7 \mathrm{~Hz}), 7.23(1 \mathrm{H}, \mathrm{t}, J=8.7 \mathrm{~Hz}), 7.16(1 \mathrm{H}, \mathrm{t}, J=7.8$ Hz), 6.82-6.64 (2 H, m), 5.90 (1 H, s), 5.64-5.43 (1 H, m), 3.82-3.68 (1 H, m), 3.23-3.02 (1 H, m), 2.65-2.46 (2 H, m), 1.60-1.43 (9 H, m) ppm. $-{ }^{13} \mathrm{C}$ NMR (125 MHz, $\mathrm{CD}_{3} \mathrm{CN}$, rotamers): $155.3\left(\mathrm{dd},{ }^{1} J_{C-F}=256.7,{ }^{3} J_{C-F}=11.1\right.$ 
$\mathrm{Hz}), 153.4,152.0\left(\mathrm{ddd},{ }^{1} J_{C-F}=254.7,{ }^{2} J_{C-F}=15.1,{ }^{3} J_{C-F}=12.5 \mathrm{~Hz}\right), 150.82,150.75,147.2$ $\left(\mathrm{dd},{ }^{1} J_{C-F}=245.3,{ }^{3} J_{C-F}=14.0 \mathrm{~Hz}\right), 135.9\left(\mathrm{~d},{ }^{2} J_{C-F}=8.9 \mathrm{~Hz}\right), 130.4,130.2,126.1,126.0$, 125.1, 125.0, 124.6, 118.6, 118.6, $117.3,109.6\left(\mathrm{~d},{ }^{2} J_{C-F}=21.1 \mathrm{~Hz}\right), 106.9\left(\mathrm{dd},{ }^{2} J_{C-F}=26.2\right.$, $\left.{ }^{2} J_{C-F}=22.1 \mathrm{~Hz}\right), 105.9\left(\mathrm{~d},{ }^{2} J_{C-F}=20.7 \mathrm{~Hz}\right), 106.3\left(\mathrm{~d},{ }^{2} J_{C-F}=20.4 \mathrm{~Hz}\right), 90.9,90.0,79.9$, 79.6, 77.9, 77.8, 45.3, 44.8, 34.3, 33.9, 27.6 ppm. $-{ }^{19} \mathrm{~F} \mathrm{NMR} \mathrm{(471} \mathrm{MHz,} \mathrm{CD}_{3} \mathrm{CN}$, rotamers): $-127.22(\mathrm{td}, J=15.3,7.2 \mathrm{~Hz}),-130.78(\mathrm{ddt}, J=25.7,9.6,5.2 \mathrm{~Hz}),-142.40-142.73(\mathrm{~m}) \mathrm{ppm}$. - IR: 3380, 2978, 1750, 1697, 1609, 1393, 1368, 1278, 1263, 1173, 1135, $1048 \mathrm{~cm}^{-1}$. HRMS calcd for $\mathrm{C}_{21} \mathrm{H}_{21} \mathrm{~F}_{3} \mathrm{~N}_{4} \mathrm{O}_{2} \mathrm{Na}$ : 441.1509, found [M+Na ${ }^{+}$] 441.1501 .

\section{1-(tert-Butyl)-2-methyl $\left(2 S^{*}, 3 \mathrm{a} R^{*}, 8 \mathrm{a} S^{*}\right)-3 \mathrm{a}-((\mathrm{E})-(3,5-$}

bis(trifluo romethyl) phenyl)diazeny l)-3,3a,8,8a-te trahy dropy rrolo $[2,3-b]$ indole-1,2(2H)dicarboxylate (S4)

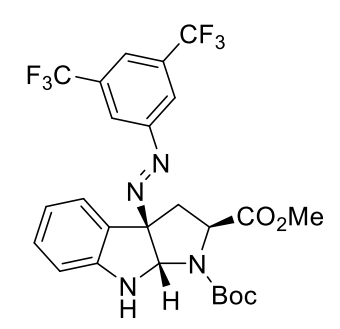

Yellow oil. $-{ }^{1} \mathrm{H}$ NMR (300 MHz, $\left(\mathrm{CD}_{3}\right)_{2} \mathrm{CO}$, rotamers): 8.35-8.19 (m, $3 \mathrm{H}), 7.24-7.06(\mathrm{~m}, 2 \mathrm{H}), 6.84-6.63(\mathrm{~m}, 2 \mathrm{H}), 6.31-6.15(\mathrm{~m}, 2 \mathrm{H}), 4.41-$ $4.27(\mathrm{~m}, 1 \mathrm{H}), 3.75-3.58(\mathrm{~m}, 3 \mathrm{H}), 3.13-2.97(\mathrm{~m}, 1 \mathrm{H}), 2.95-2.77(\mathrm{~m}, 1 \mathrm{H})$, 1.59-1.35 (m, 9H) ppm. $-{ }^{13} \mathrm{C} \mathrm{NMR}\left(75 \mathrm{MHz},\left(\mathrm{CD}_{3}\right)_{2} \mathrm{CO}\right.$, rotamers): $170.4,153.3,151.1,137.1,133.6,133.2\left(\mathrm{q},{ }^{2} J_{C-F}=33.7 \mathrm{~Hz}\right), 131.2$, 131.1, 129.8, 129.3, 128.5, 128.2, 126.5, $125.4\left(\mathrm{q},{ }^{3} J_{C-F}=3.5 \mathrm{~Hz}\right), 123.9\left(\mathrm{q},{ }^{3} J_{C-F}=3.5 \mathrm{~Hz}\right)$, $124.2\left(\mathrm{q},{ }^{1} J_{C-F}=272.1 \mathrm{~Hz}\right) 123.5,118.3,111.8,90.3,79.0,49.5,35.8 \mathrm{ppm} .-{ }^{19} \mathrm{~F}$ NMR $(471$ $\mathrm{MHz},\left(\mathrm{CD}_{3}\right)_{2} \mathrm{CO}$, rotamers): -63.40 ppm. - IR: 3359, 3060, 2976, 1686, 1609, 1506, 1481, 1470, 1393, 1368, 1334, 1315, 1292, 1256, 1212, 1162, 1117, 1069, 1043, $891 \mathrm{~cm}^{-1}$. HRMS calcd for $\mathrm{C}_{25} \mathrm{H}_{25} \mathrm{~F}_{6} \mathrm{~N}_{4} \mathrm{O}_{4}: 559.1775$, found $\left[\mathrm{M}+\mathrm{H}^{+}\right]$559.1769.

$\left(3 \mathrm{a} R *, 8 \mathrm{a} S^{*}\right)-3 \mathrm{a}-((E)-$ Phenyldiazenyl)-1-tosyl-1,2,3,3a,8,8a-hexahy dropy rrolo $[2,3-$

\section{b]indole (S5)}

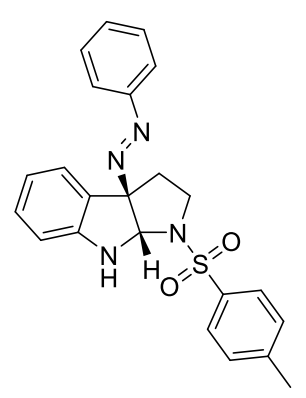

Yellow solid. - m.p.: $144-146{ }^{\circ} \mathrm{C} .{ }^{1} \mathrm{H}$ NMR (500 MHz, DMSO-d 6 $/ \mathrm{CD}_{3} \mathrm{CN}$ 2:1 v/v, rotamers): 7.29-7.16 $(2 \mathrm{H}, \mathrm{m}), 6.95(5 \mathrm{H}, \mathrm{s}), 6.83-6.71$ $(2 \mathrm{H}, \mathrm{m}), 6.56(2 \mathrm{H}, \mathrm{ddd}, J=15.5,7.9,1.3 \mathrm{~Hz}), 6.20-6.04(3 \mathrm{H}, \mathrm{m}), 5.49$ $(1 \mathrm{H}, \mathrm{d}, J=2.8 \mathrm{~Hz}), 2.98$ (1 H, ddd, $J=10.9,7.6,3.4 \mathrm{~Hz}), 2.64-2.57(1 \mathrm{H}$, m), $1.90-1.52(5 \mathrm{H}, \mathrm{m}) \mathrm{ppm} .-{ }^{13} \mathrm{C} \mathrm{NMR}\left(125 \mathrm{MHz}, \mathrm{DMSO}-d_{6} / \mathrm{CD}_{3} \mathrm{CN}\right.$ $2: 1 \mathrm{v} / \mathrm{v}$, rotamers): $151.3,150.4,143.9,135.8,131.3,130.0,129.8,129.3$, $127.5,126.7,124.7,122.2,118.4,109.4,90.8,80.6,47.2$, 35.6, 20.7 ppm. - IR: 3399, 2257, 
2128, 1652, 1049, 1023, $1002 \mathrm{~cm}^{-1}$. - HRMS calcd for $\mathrm{C}_{23} \mathrm{H}_{23} \mathrm{~N}_{4} \mathrm{O}_{2} \mathrm{~S}$ : 419.1536, found $\left[\mathrm{M}+\mathrm{H}^{+}\right] 419.1535$.

$(3 \mathrm{a} R *, 8 \mathrm{a} S *)-3 \mathrm{a}-((E)-(4-M e t h o x y-2-n i t r o p h e n y l)$ diazenyl)-3,3a,8,8a-tetrahy dro-2Hfuro[2,3-b]indole (S6)

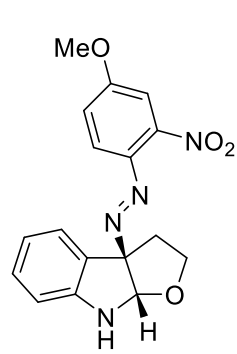

Yellow oil. - ${ }^{1} \mathrm{H}$ NMR (500 MHz, $\mathrm{C}_{6} \mathrm{D}_{6}$, rotamers): 8.54-7.60 (1 H, m), 7.35-7.21 (1 H, m), 7.01-6.86 (4 H, m), 6.83-6.77 (1 H, m), 6.49-6.40 (1 H, m), 3.77-3.54 (1 H, m), 3.29-3.11 (1 H, m), 2.92 (3 H, s), 2.47-2.20 (1 H, m), 1.97-1.82 (1 H, m) ppm. $-{ }^{13} \mathrm{C}$ NMR (125 MHz, $\mathrm{C}_{6} \mathrm{D}_{6}$, rotamers): 161.5, $142.6,139.4,137.2,130.5,130.0,126.5,125.9,119.3,118.6,118.6,116.3$, 110.9, 107.4, 107.4, 98.2, 91.8, 89.1, 88.8, 68.1, 55.1, 37.2 ppm. - IR: 3408, 2880, 1612, 1530, 1488, 1469, 1443, 1356, 1326, 1280, 1242, 1153, $1078 \mathrm{~cm}^{-1}$. - HRMS calcd for $\mathrm{C}_{17} \mathrm{H}_{16} \mathrm{~N}_{4} \mathrm{O}_{4} \mathrm{Na}: 363.1064$, found $\left[\mathrm{M}+\mathrm{Na}^{+}\right]$363.1057.

$(3 \mathrm{a} R *, 8 \mathrm{a} S *)-3 \mathrm{a}-((E)-(4-I o d o p h e n y l) d i a z e n y l)-1-t o s y l-1,2,3,3 \mathrm{a}, 8,8 \mathrm{a}-$ hexahydropyrrolo[2,3-b]indole (S7)

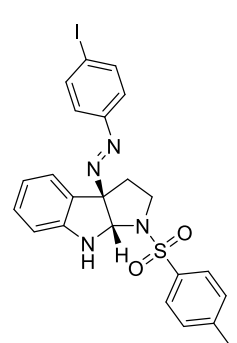

Orange solid. - m.p.: $151-155{ }^{\circ} \mathrm{C} .-{ }^{1} \mathrm{H}$ NMR $\left(500 \mathrm{MHz}, \mathrm{DMSO}-d_{6} / \mathrm{CD}_{3} \mathrm{CN}\right.$ $2: 1 \mathrm{v} / \mathrm{v}$, rotamers): $7.88(2 \mathrm{H}, \mathrm{d}, J=8.4 \mathrm{~Hz}), 7.78(2 \mathrm{H}, \mathrm{d}, J=8.0 \mathrm{~Hz}), 7.38-$ $7.23(4 \mathrm{H}, \mathrm{m}), 7.12$ (2 H, ddd, $J=9.0,7.5,3.0 \mathrm{~Hz}), 6.74-6.61(2 \mathrm{H}, \mathrm{m}), 6.48$ $(1 \mathrm{H}, \mathrm{d}, J=2.8 \mathrm{~Hz}), 6.02(1 \mathrm{H}, \mathrm{d}, J=2.8 \mathrm{~Hz}), 3.54(1 \mathrm{H}$, ddd, $J=11.0,7.6$, $3.5 \mathrm{~Hz}), 3.21(1 \mathrm{H}, \mathrm{td}, J=10.3,6.0 \mathrm{~Hz}), 2.41-2.29(4 \mathrm{H}, \mathrm{m}), 2.19(1 \mathrm{H}, \mathrm{ddd}, J$ $=12.8,9.7,7.6 \mathrm{~Hz}) \mathrm{ppm} .-{ }^{13} \mathrm{C} \mathrm{NMR}\left(125 \mathrm{MHz}, \mathrm{DMSO}-d_{6} / \mathrm{CD}_{3} \mathrm{CN} 2: 1 \mathrm{v} / \mathrm{v}\right.$, rotamers $)$ : $150.7,150.5$, 144.0, 138.5, 135.8, 130.2, 129.9, 127.5, 126.5, 124.8, 124.1, 118.5, 109.5, 98.0, 91.1, 80.6, 47.3, 35.6, 20.8 ppm. - IR: 3417, 2251, 2128, 1657, 1051, 1024, $1005 \mathrm{~cm}^{-1}$. - HRMS calcd for $\mathrm{C}_{23} \mathrm{H}_{22} \mathrm{IN}_{4} \mathrm{O}_{2} \mathrm{~S}: 545.0503$, found $\left[\mathrm{M}+\mathrm{H}^{+}\right]$545.0495.

tert-Butyl (3a $\left.R^{*}, 8 \mathrm{a} S^{*}\right)-3 \mathrm{a}-((E)-(4-m e t h o x y-2-n i t r o p h e n y l) d i a z e n y l)-3,3 a, 8,8 a-$ tetrahydropy rrolo $[2,3-b]$ indole- $1(2 \mathrm{H})$-carboxylate $(\mathrm{S8})$

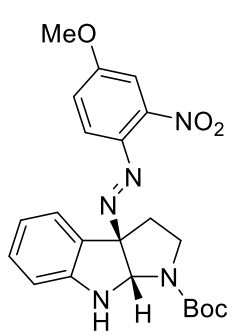
Yellow solid. - m.p.: $95-98{ }^{\circ} \mathrm{C}$. $-{ }^{1} \mathrm{H}$ NMR (500 MHz, $\mathrm{CD}_{3} \mathrm{CN}$, rotamers): 7.48-7.30 (2 H, m), 7.24-7.04 (3 H, m), 6.76-6.58 (2 H, m), 5.90-5.78 (1 H, m), 5.57-5.39 (1 H, m), $3.87(3 \mathrm{H}, \mathrm{s}), 3.77-3.62(1 \mathrm{H}, \mathrm{m}), 3.17-3.01(1 \mathrm{H}$, 
m), 2.56-2.34 (2 H, m), 1.58-1.38 (9 H, m) ppm. - ${ }^{13} \mathrm{C} \mathrm{NMR} \mathrm{(75} \mathrm{MHz,} \mathrm{CD}_{3} \mathrm{CN}$, rotamers): $161.7,150.7,148.7,137.4,130.1$, 125.0, 119.8, 118.9, 118.6, 109.6, 109.5, 108.5, 90.7, 79.8, 78.1, 56.3, 45.4, 44.8, 34.0, 33.7, 27.6 ppm. - IR: 3358, 2975, 1686, 1610, 1533, 1483, 1470, $1405,1365,1317,1279,1241,1206,1163,1069,1028 \mathrm{~cm}^{-1}$. - HRMS calcd for $\mathrm{C}_{22} \mathrm{H}_{26} \mathrm{~N}_{5} \mathrm{O}_{5}$ : 440.1928, found $\left[\mathrm{M}+\mathrm{H}^{+}\right]$440.1927.

1-((3a $\left.R^{*}, 8 \mathrm{a} S^{*}\right)-3 \mathrm{a}-((E)$-Phenyldiazeny $\mathrm{l})-3,3 \mathrm{a}, 8,8 \mathrm{a}-$ tetrahy dropy rrolo[2,3-b]indol-1(2H)yl)ethan-1-one (S9)

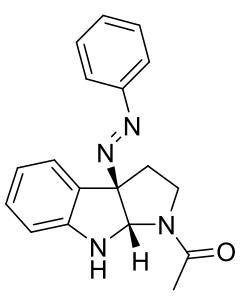

Yellow oil. $-{ }^{1} \mathrm{H}$ NMR (500 MHz, $\mathrm{CD}_{3} \mathrm{CN}$, rotamers): 7.74-7.62 (2 H, m), 7.56-7.42 (3 H, m), 7.31-7.10 (2 H, m), 6.88-6.62 (2 H, m), 6.18-5.92 (1 $\mathrm{H}, \mathrm{m}), 5.73-5.61$ (1 H, m), 4.08-3.78 (1 H, m), 3.42-3.01 (1 H, m), 2.74$2.45(2 \mathrm{H}, \mathrm{m}), 2.23-1.98(3 \mathrm{H}, \mathrm{m}) \mathrm{ppm} .-{ }^{13} \mathrm{C} \mathrm{NMR}\left(125 \mathrm{MHz}, \mathrm{CD}_{3} \mathrm{CN}\right.$, rotamers): $170.0,169.1,151.82,151.77,150.9,150.6,131.14,131.09$, $130.1,130.0,129.29,129.25,129.2,127.5,126.5,125.0,124.9,122.11,122.06,119.3,118.5$, 110.0, 109.5, 91.4, 88.7, 78.3, 77.5, 46.6, 44.0, 34.1, 34.0, 21.6, 21.4 ppm. - IR: 3327, 3053, $2973,2875,1635,1608,1481,1469,1440,1418,1346,1317,1231,1202,1170,1063 \mathrm{~cm}^{-1}$. HRMS calcd for $\mathrm{C}_{18} \mathrm{H}_{19} \mathrm{~N}_{4} \mathrm{O}: 307.1553$, found $\left[\mathrm{M}+\mathrm{H}^{+}\right] 307.1550$.

\section{Benzyl (3a $\left.R^{*}, 8 \mathrm{a} S *\right)-3 \mathrm{a}-((E)-(3,5-b i s($ trifluo romethyl)phenyl)diazenyl)-3,3a,8,8a-} tetrahydropy rrolo $[2,3-b]$ indole-1 $(2 H)$-carboxylate $(\mathrm{S10})$

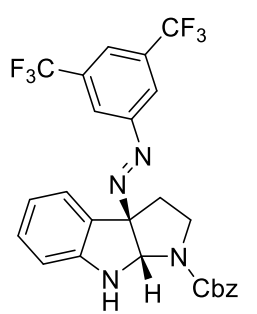

Orange solid. - m.p.: $111-113{ }^{\circ} \mathrm{C} .-{ }^{1} \mathrm{H}$ NMR (500 MHz, $\mathrm{CD}_{3} \mathrm{CN}$, rotamers): 8.40-7.84 (5 H, m), 7.58-7.24 (5 H, m), 7.22-6.67 (2 H, m), 6.61-5.53 (2 H, m), 5.38-5.08 (2 H, m), 3.99-3.80 (1 H, m), 3.50-3.14 (1 H, m), 2.88-2.50 (2 H, m) ppm. $-{ }^{13} \mathrm{C}$ NMR (125 MHz, $\mathrm{CD}_{3} \mathrm{CN}$, rotamers): 154.9, 154.7, $153.6,152.4,152.3,150.7,145.5,137.1,132.2\left(\mathrm{q},{ }^{2} J_{C-F}=33.6 \mathrm{~Hz}\right), 132.07$ $\left(\mathrm{q},{ }^{2} J_{C-F}=33.7 \mathrm{~Hz}\right), 130.3,129.7,128.5,128.04,127.98,127.9\left(\mathrm{q},{ }^{3} J_{C-F}=7.0 \mathrm{~Hz}\right), 127.8(\mathrm{q}$, $\left.{ }^{3} J_{C-F}=4.8 \mathrm{~Hz}\right), 127.24,127.19,125.2,125.1,124.5,123.4\left(\mathrm{q},{ }^{1} J_{C-F}=276.4 \mathrm{~Hz}\right), 122.9$, $122.8,122.5,120.1,118.8$ (q, ${ }^{3} J_{C-F}=4.6 \mathrm{~Hz}$ ), 117.3, 109.7, 108.8, 91.1, 90.3, 90.0, 89.2, $78.4,78.1,77.9,77.5,66.9,66.7,66.5,45.3,45.2,34.7,34.2,33.8$ ppm. $-{ }^{19} \mathrm{~F}$ NMR (471 $\mathrm{MHz}, \mathrm{CD}_{3} \mathrm{CN}$, rotamers): -63.44 ppm. - IR: 3373, 2258, 2130, 1646, 1046, 1023, $992 \mathrm{~cm}^{-1}$.HRMS calcd for $\mathrm{C}_{26} \mathrm{H}_{20} \mathrm{~F}_{6} \mathrm{~N}_{4} \mathrm{O}_{2} \mathrm{Na}$ : 535.1563, found $\left[\mathrm{M}+\mathrm{Na}^{+}\right]$535.1556. 


\section{Benzyl (3a $R *, 8 \mathrm{a} S *)-3 \mathrm{a}-((E)-(2,4,5$-trifluorophenyl)diazenyl)-3,3a,8,8a-}

\section{tetrahydropy rrolo $[2,3-b]$ indole-1 $(2 H)$-carboxylate $(\mathrm{S} 11)$}

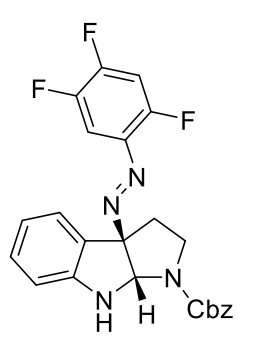

Yellow solid. - m.p.: $123-125{ }^{\circ} \mathrm{C} .-{ }^{1} \mathrm{H}$ NMR (500 MHz, $\mathrm{CD}_{3} \mathrm{CN}$, rotamers): 7.86-7.77 (2 H, m), $7.64(1 \mathrm{H}, \mathrm{ddd}, J=11.5,8.8,7.0 \mathrm{~Hz}), 7.53-7.24(7 \mathrm{H}$, m), $6.78(1 \mathrm{H}, \mathrm{d}, J=8.4 \mathrm{~Hz}), 6.37(1 \mathrm{H}, \mathrm{d}, J=44.4 \mathrm{~Hz}), 6.09(1 \mathrm{H}, \mathrm{d}, J=$ 11.6 Hz), 5.36-5.05 (2 H, m), 3.92-3.77 (1 H, m), 3.47-3.18 (1 H, m), 2.72$2.47(2 \mathrm{H}, \mathrm{m}) \mathrm{ppm} .-{ }^{13} \mathrm{C} \mathrm{NMR}\left(125 \mathrm{MHz}, \mathrm{CD}_{3} \mathrm{CN}\right.$, rotamers): $156.4\left(\mathrm{dd},{ }^{1} J_{C}\right.$ $\left.F=248.4,{ }^{3} J_{C-F}=9.4 \mathrm{~Hz}\right), 156.1\left(\mathrm{dd},{ }^{1} J_{C-F}=253.4,{ }^{3} J_{C-F}=9.5 \mathrm{~Hz}\right), 155.6,155.5,153.2(\mathrm{ddd}$, $\left.{ }^{1} J_{C-F}=255.1,{ }^{2} J_{C-F}=15.0,{ }^{3} J_{C-F}=12.5 \mathrm{~Hz}\right), 151.8\left(\mathrm{ddd},{ }^{1} J_{C-F}=252.5,{ }^{2} J_{C-F}=14.7,{ }^{3} J_{C-F}=\right.$ $12.0 \mathrm{~Hz}), 148.3\left(\mathrm{dt},{ }^{1} J_{C-F}=246.1,{ }^{3} J_{C-F}=11.0 \mathrm{~Hz}\right), 146.8,138.3,138.0,136.7\left(\mathrm{dt},{ }^{2} J_{C-F}=9.1\right.$ $\left.\mathrm{Hz},{ }^{3} J_{C-F}=3.2 \mathrm{~Hz}\right), 131.3,130.6,129.5,129.0,128.9,129,7,128.3,120.4,118.3,110.7$, $109.8,108.0\left(\mathrm{dd},{ }^{2} J_{C-F}=26.2,{ }^{2} J_{C-F}=22.3 \mathrm{~Hz}\right), 107.7\left(\mathrm{dd},{ }^{2} J_{C-F}=26.4,{ }^{2} J_{C-F}=22.0 \mathrm{~Hz}\right)$, $107.0\left(\mathrm{~d},{ }^{2} J_{C-F}=20.8 \mathrm{~Hz}\right), 106.3\left(\mathrm{~d},{ }^{2} J_{C-F}=20.4 \mathrm{~Hz}\right), 91.2,90.1,79.6,78.9,67.9,67.7,46.2$, 46.1, 35.7, 35.3 ppm. $-{ }^{19} \mathrm{~F}$ NMR (471 MHz, $\mathrm{CD}_{3} \mathrm{CN}$, rotamers): -126.87 (ddd, $J=15.6,10.3$, $5.8 \mathrm{~Hz}),-127.81$ (td, $J=10.2,4.3 \mathrm{~Hz}),-130.07-130.37(\mathrm{~m}),-133.31$ (ddt, $J=20.3,10.2,5.1$ $\mathrm{Hz}),-142.27-142.65$ (m), -142.90--143.41 (m) ppm. - IR: $\mathrm{cm}^{-1}$. - HRMS calcd for $\mathrm{C}_{24} \mathrm{H}_{19} \mathrm{~F}_{3} \mathrm{~N}_{4} \mathrm{O}_{2} \mathrm{Na}$ : 453.1533, found $\left[\mathrm{M}+\mathrm{Na}^{+}\right]$453.1532.

\section{Benzyl (3a $\left.R^{*}, 8 \mathrm{a} S^{*}\right)-3 \mathrm{a}-((E)-(4-i o d o p h e n y l)$ diazenyl)-3,3a,8,8a-tetrahydropy rrolo[2,3- b]indole-1(2H)-carboxylate (S12)}

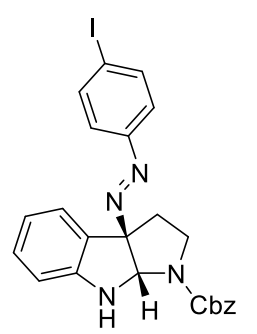

Orange solid. - m.p.: $143-145{ }^{\circ} \mathrm{C} .-{ }^{1} \mathrm{H}$ NMR $\left(500 \mathrm{MHz}\right.$, DMSO- $d_{6} / \mathrm{CD}_{3} \mathrm{CN}$ 2:1 v/v, rotamers): $7.89(2 \mathrm{H}, \mathrm{dd}, J=8.6,2.0 \mathrm{~Hz}), 7.55-7.29(7 \mathrm{H}, \mathrm{m}), 7.28-$ 7.05 (2 H, m), 6.78-6.39 (3 H, m), 6.13-5.88 (1 H, m), 5.31-5.06 (2 H, m), 3.89-3.76 (1 H, m), 3.18-3.10 (1 H, m), 2.58-2.51 (2 H, m) ppm. $-{ }^{13} \mathrm{C} \mathrm{NMR}$ (125 MHz, DMSO- $d_{6} / \mathrm{CD}_{3} \mathrm{CN} 2: 1 \mathrm{v} / \mathrm{v}$, rotamers): $153.9,153.5,150.6,150.5$, $138.1,136.8,136.7,130.9$, 129.7, 129.7, 129.6, 129.0, 128.2, 128.1, 127.62, 127.58, 127.4, $125.9,124.5,123.7,121.8,117.9,117.7,109.2$, 109.0, 97.7, 90.2, 89.2, 77.4, 76.9, 66.2, 66.0, 44.9, 44.7, 34.3, 33.8 ppm. - IR: 3305, 1683, 1604, 1480, 1448, 1350, 1308, 1259, 1199, 1103, 1023, $969 \mathrm{~cm}^{-1}$. - HRMS calcd for $\mathrm{C}_{24} \mathrm{H}_{21} \mathrm{IN}_{4} \mathrm{O}_{2} \mathrm{Na}$ : 547.0601, found [M+Na $\left.{ }^{+}\right]$ 547.0593. 


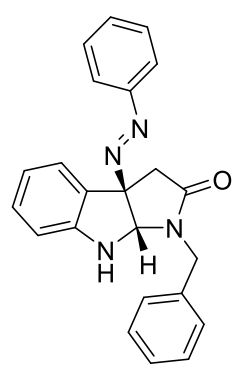

Yellow solid. - m.p.: $112-115{ }^{\circ} \mathrm{C} .-{ }^{1} \mathrm{H}$ NMR (500 $\mathrm{MHz}, \mathrm{CD}_{3} \mathrm{CN}$, rotamers): $7.64(2 \mathrm{H}, \mathrm{dd}, J=6.6,3.1 \mathrm{~Hz}), 7.55-7.46(3 \mathrm{H}, \mathrm{m}), 7.43-7.25(6 \mathrm{H}, \mathrm{m}), 7.21$ $(1 \mathrm{H}, \mathrm{t}, J=7.7 \mathrm{~Hz}), 6.85(1 \mathrm{H}, \mathrm{t}, J=7.5 \mathrm{~Hz}), 6.76(1 \mathrm{H}, \mathrm{d}, J=7.9 \mathrm{~Hz}), 5.70$ $(1 \mathrm{H}, \mathrm{d}, J=3.4 \mathrm{~Hz}), 5.54(1 \mathrm{H}, \mathrm{d}, J=3.5 \mathrm{~Hz}), 4.89(1 \mathrm{H}, \mathrm{d}, J=15.3 \mathrm{~Hz}), 4.30$ $(1 \mathrm{H}, \mathrm{d}, J=15.3 \mathrm{~Hz}), 3.36(1 \mathrm{H}, \mathrm{d}, J=17.4 \mathrm{~Hz}), 3.04(1 \mathrm{H}, \mathrm{d}, J=17.4 \mathrm{~Hz})$ ppm. $-{ }^{13} \mathrm{C}$ NMR (125 MHz, , $\mathrm{CD}_{3} \mathrm{CN}$, rotamers): 170.7, 151.6, 149.7, 136.9, $131.3,130.3,129.5,129.3,128.6,127.9,127.4,125.4,122.2,119.8,111.2,83.1,78.3,43.3$, 40.0 ppm. - IR: 3294, 3060, 2931, 1673, 1607, 1483, 1449, 1413, 1338, 1313, 1279, 1171, 1151, 1095, 1027, $924 \mathrm{~cm}^{-1}$. - HRMS calcd for $\mathrm{C}_{23} \mathrm{H}_{21} \mathrm{~N}_{4} \mathrm{O}: 369.1710$, found $\left[\mathrm{M}+\mathrm{H}^{+}\right]$ 369.1708 .

((3a $\left.R^{*}, 8 \mathrm{a} S^{*}\right)-3 \mathrm{a}-((\boldsymbol{E})-(3,5-B i s($ trifluoromethyl)phenyl)diazenyl)-5-chloro-3,3a,8,8atetrahydropy rrolo $[2,3-b]$ indol-1 $(2 H)-y l)($ phenyl)methanone (2)

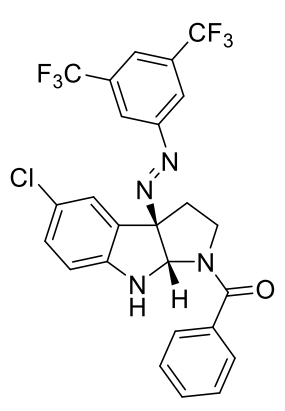

Orange solid. - m.p.: 141-143 ${ }^{\circ} \mathrm{C} .-{ }^{1} \mathrm{H}$ NMR $\left(500 \mathrm{MHz},\left(\mathrm{CD}_{3}\right)_{2} \mathrm{CO}\right.$, rotamers): $8.35(2 \mathrm{H}, \mathrm{s}), 8.21(1 \mathrm{H}, \mathrm{s}), 7.66-7.37(5 \mathrm{H}, \mathrm{m}), 7.34(1 \mathrm{H}, \mathrm{d}, J=$ $2.2 \mathrm{~Hz}), 7.15(1 \mathrm{H}, \mathrm{d}, J=8.5 \mathrm{~Hz}), 6.76(1 \mathrm{H}, \mathrm{d}, J=8.4 \mathrm{~Hz}), 6.43(2 \mathrm{H}, \mathrm{s})$, 4.45-3.75 (1 H, m), 3.72-3.22 (1 H, m), 2.78-2.61 (2 H, m) ppm. $-{ }^{13} \mathrm{C}$ NMR (125 MHz, $\mathrm{CD}_{3} \mathrm{CN}$, rotamers): 169.8, 169.0, 154.2, 153.5, 152.5, $144.9,144.4,132.2\left(\mathrm{q},{ }^{2} J_{C-F}=33.7 \mathrm{~Hz}\right), 128.4,127.0,124.3\left(\mathrm{q},{ }^{3} J_{C-F}=4.3\right.$

$\mathrm{Hz}), 123.2\left(\mathrm{q},{ }^{1} J_{C-F}=271.5 \mathrm{~Hz}\right), 122.8\left(\mathrm{q},{ }^{3} J_{C-F}=3.9 \mathrm{~Hz}\right), 117.3,116.1,115.9,111.6,111.2$, $110.8,110.5,92.6,89.8,79.0,78.2,55.5,46.6,44.0,34.0,33.8,21.5,21.4 \mathrm{ppm} .-{ }^{19} \mathrm{~F} \mathrm{NMR}$ (471 MHz, $\mathrm{CD}_{3} \mathrm{CN}$, rotamers): -63.41 ppm. - IR: 3328, 1627, 1577, 1480, 1447, 1416, 1369, 1278, 1177, 1136, $1086 \mathrm{~cm}^{-1}$. - HRMS calcd for $\mathrm{C}_{25} \mathrm{H}_{18} \mathrm{ClF}_{6} \mathrm{~N}_{4} \mathrm{O}: 539.1068$, found $\left[\mathrm{M}+\mathrm{H}^{+}\right]$ 539.1067.

\section{1-((3a $\left.R^{*}, 8 \mathrm{a} S *\right)-3 \mathrm{a}-((E)-(3,5-\mathrm{B}$ is (trifluoromethyl)phenyl) diazenyl)-5-methoxy -3,3a,8,8a-} tetrahydropy rrolo[2,3-b]indol-1 (2H)-yl)ethan-1-one (3)

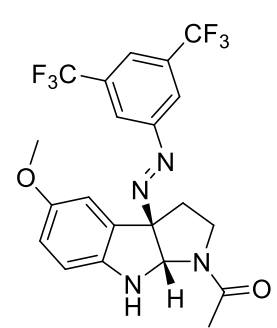

Yellow oil. $-{ }^{1} \mathrm{H}$ NMR (500 MHz, $\mathrm{CD}_{3} \mathrm{CN}$, rotamers): 8.27-8.06 (3 H, m), 6.97-6.91 (1 H, m), 6.85-6.76 (1 H, m), 6.72-6.61 (1 H, m), 6.21-5.96 (1 H, m), 5.32 (1 H, s), 4.16-3.80 (1 H, m), 3.80-3.64 (3 H, m), 3.46-3.02 (1 
$\mathrm{H}, \mathrm{m}), 2.78-2.49(2 \mathrm{H}, \mathrm{m}), 2.10(3 \mathrm{H}, \mathrm{m}) \mathrm{ppm} .-{ }^{13} \mathrm{C} \mathrm{NMR}\left(125 \mathrm{MHz}, \mathrm{CD}_{3} \mathrm{CN}\right.$, rotamers): ppm. $-{ }^{19} \mathrm{~F}$ NMR (471 MHz, $\mathrm{CD}_{3} \mathrm{CN}$, rotamers): -63.42 ppm - IR: 3528, 2261, 1626, 1494, 1441, 1370, 1282, 1161, 1140, 1034, $945 \mathrm{~cm}^{-1}$. - HRMS calcd for $\mathrm{C}_{21} \mathrm{H}_{19} \mathrm{~F}_{6} \mathrm{~N}_{4} \mathrm{O}_{2}$ : 473.1407, found $\left[\mathrm{M}+\mathrm{H}^{+}\right] 473.1410$.

\section{$\left(3 \mathrm{a} R^{*}, 8 \mathrm{a} S^{*}\right)-3 \mathrm{a}-((E)-N a p h t h a l e n-1$-yldiazenyl)-1-tosyl-1,2,3,3a,8,8a-} hexahydropyrrolo $[2,3-b]$ indole (4)

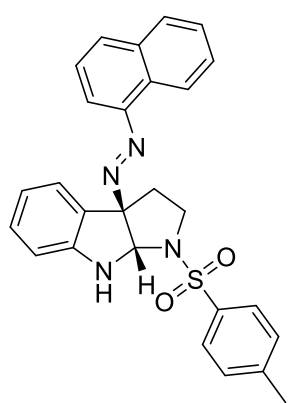

Orange solid. - m.p.: $138-140{ }^{\circ} \mathrm{C} . \quad-{ }^{1} \mathrm{H}$ NMR $\left(500 \mathrm{MHz}, \mathrm{CD}_{3} \mathrm{CN}\right.$, rotamers): 8.43-8.38 (1 H, m), 8.04-7.92 (2 H, m), 7.81-7.74 (2 H, m), 7.68-7.57 (2 H, m), $7.51(1 \mathrm{H}, \mathrm{td}, J=8.0,1.6 \mathrm{~Hz}), 7.30(1 \mathrm{H}, \mathrm{dq}, J=7.4$, $1.2 \mathrm{~Hz}), 7.23(3 \mathrm{H}, \mathrm{dd}, J=8.2,4.1 \mathrm{~Hz}), 7.16(1 \mathrm{H}, \mathrm{tt}, J=7.5,1.4 \mathrm{~Hz})$, 6.85-6.66 (2 H, m), $6.08(1 \mathrm{H}, \mathrm{d}, J=2.5 \mathrm{~Hz}), 5.56(1 \mathrm{H}, \mathrm{d}, J=2.6 \mathrm{~Hz})$, $3.61(1 \mathrm{H}$, ddd, $J=10.9,7.5,3.7 \mathrm{~Hz}), 3.36-3.24(1 \mathrm{H}, \mathrm{m}), 2.44(2 \mathrm{H}$, dtdd, $J=21.8,12.1,7.5,2.8 \mathrm{~Hz}), 2.18(3 \mathrm{H}, \mathrm{d}, J=2.1 \mathrm{~Hz}) .-{ }^{13} \mathrm{C} \mathrm{NMR}\left(125 \mathrm{MHz}, \mathrm{CD}_{3} \mathrm{CN}\right.$, rotamers): 150.2, 146.6, 144.0, 135.7, 134.1, 131.2, 130.1, 130.0, 129.8, 128.0, 127.3, 127.1, 126.8, 126.7, 125.6, 124.9, 122.6, 119.0, 112.1, 109.7, 91.5, 81.0, 47.5, 35.3, 20.4 ppm. - IR: 3387, 2052, 1609, 1482, 1469, 1342, 1279, 1160, 1093, 1042, $1015 \mathrm{~cm}^{-1}$. - HRMS calcd for $\mathrm{C}_{27} \mathrm{H}_{25} \mathrm{~N}_{4} \mathrm{O}_{2} \mathrm{~S}: 469.1693$, found $\left[\mathrm{M}+\mathrm{H}^{+}\right] 469.1690$. 
NMR Spectroscopic Data

$\left(3 \mathrm{a} R *, 8 \mathrm{a} S^{*}\right)-3 \mathrm{a}-((E)$-Phenyldiazenyl)-3,3a,8,8a-tetrahy dro-2H-furo[2,3-b]indole (S1)
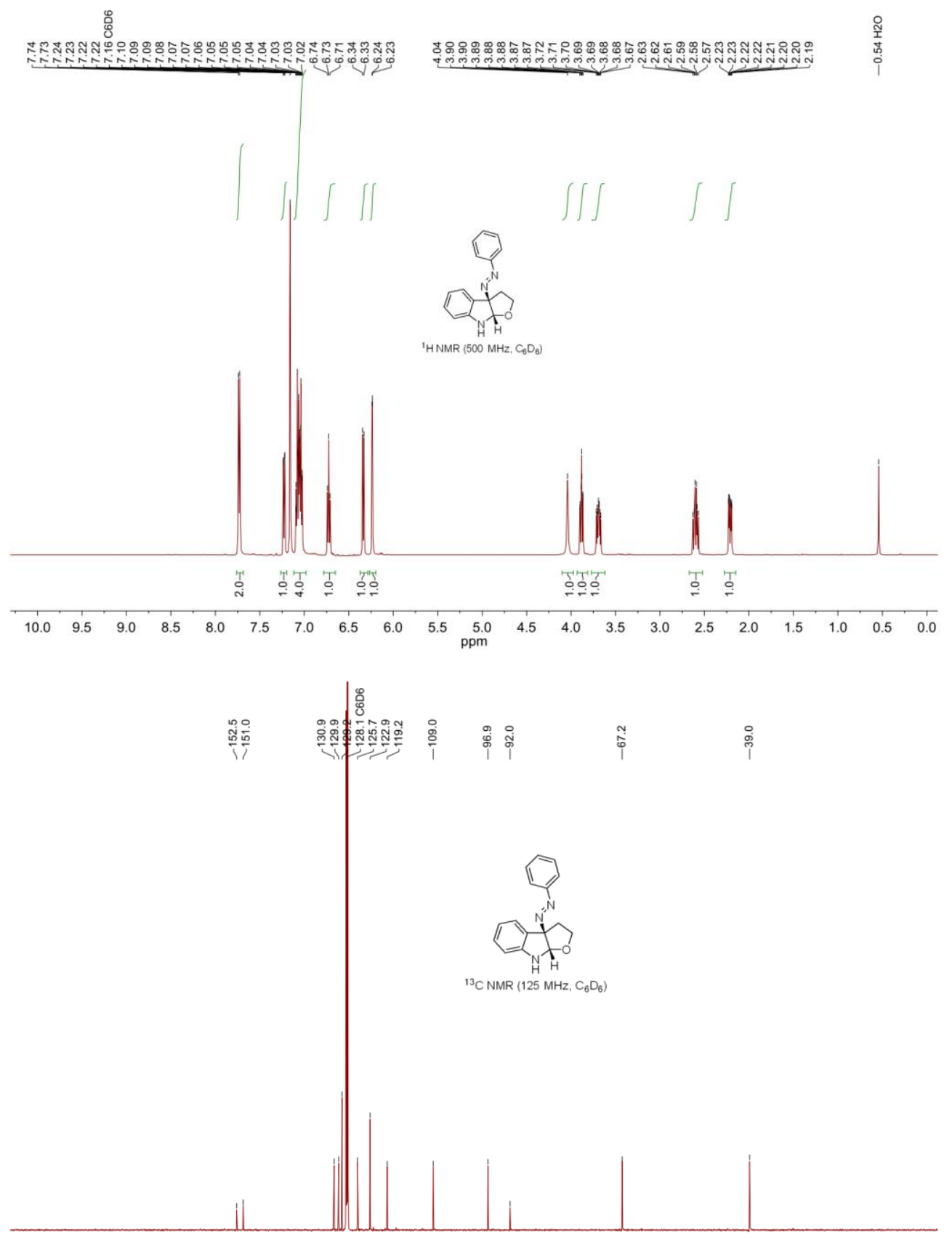

$\begin{array}{lllllllllllllllllllllllllll}200 & 190 & 180 & 170 & 160 & 150 & 140 & 130 & 120 & 110 & 100 & 90 & 80 & 70 & 60 & 50 & 40 & 30 & 20 & 10 & 0\end{array}$ 


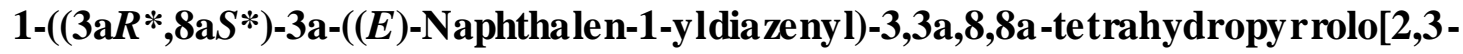

b]indol-1(2H)-yl)ethan-1-one (S2)
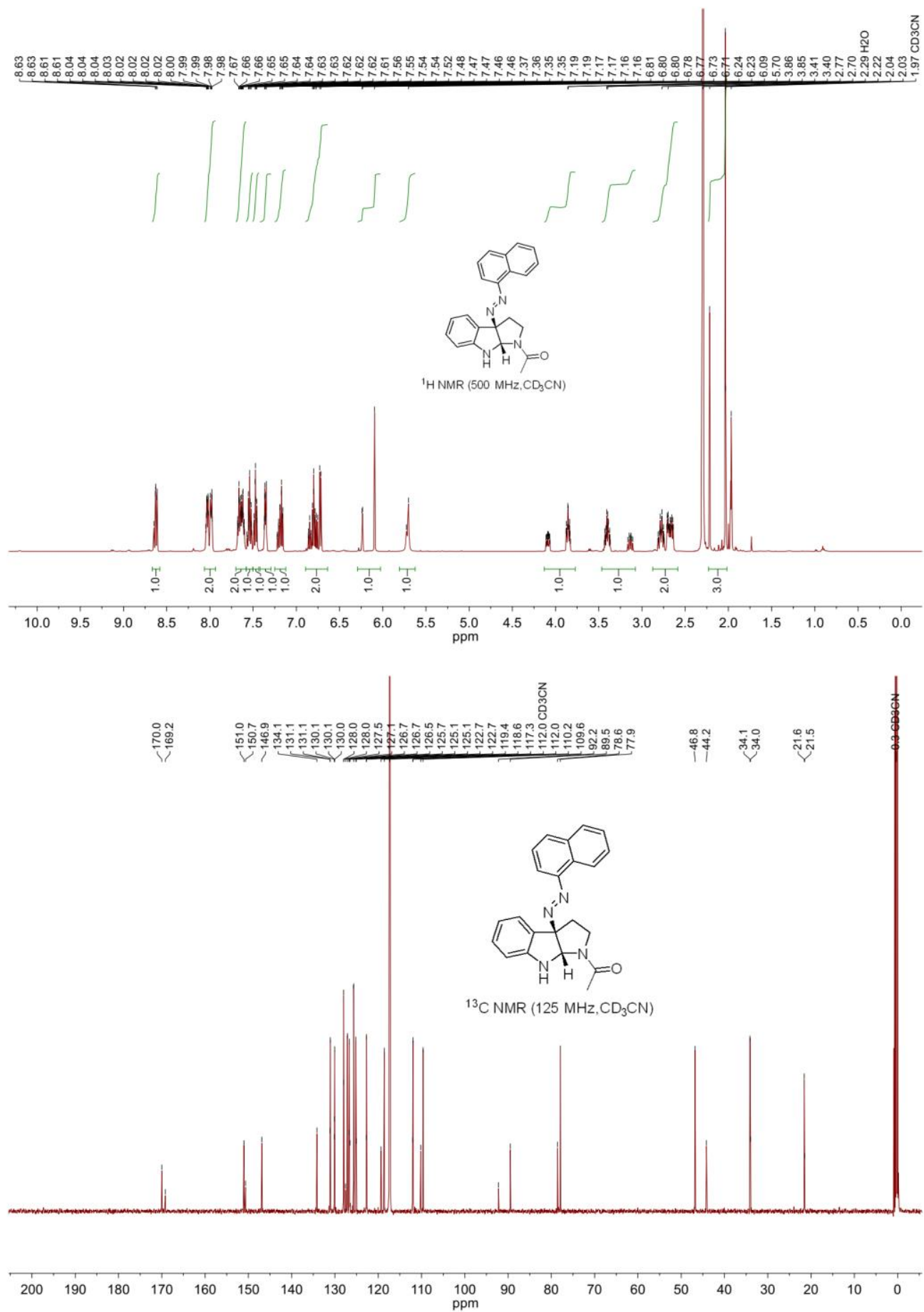
tert-Butyl (3a $R *, 8 \mathrm{a} S *)-3 \mathrm{a}-((\mathrm{E})-(2,4,5$-trifluorophenyl)diazenyl)-3,3a,8,8atetrahydropy rrolo $[2,3-b]$ indole-1 $(2 H)$-carboxylate $(\mathrm{S3})$

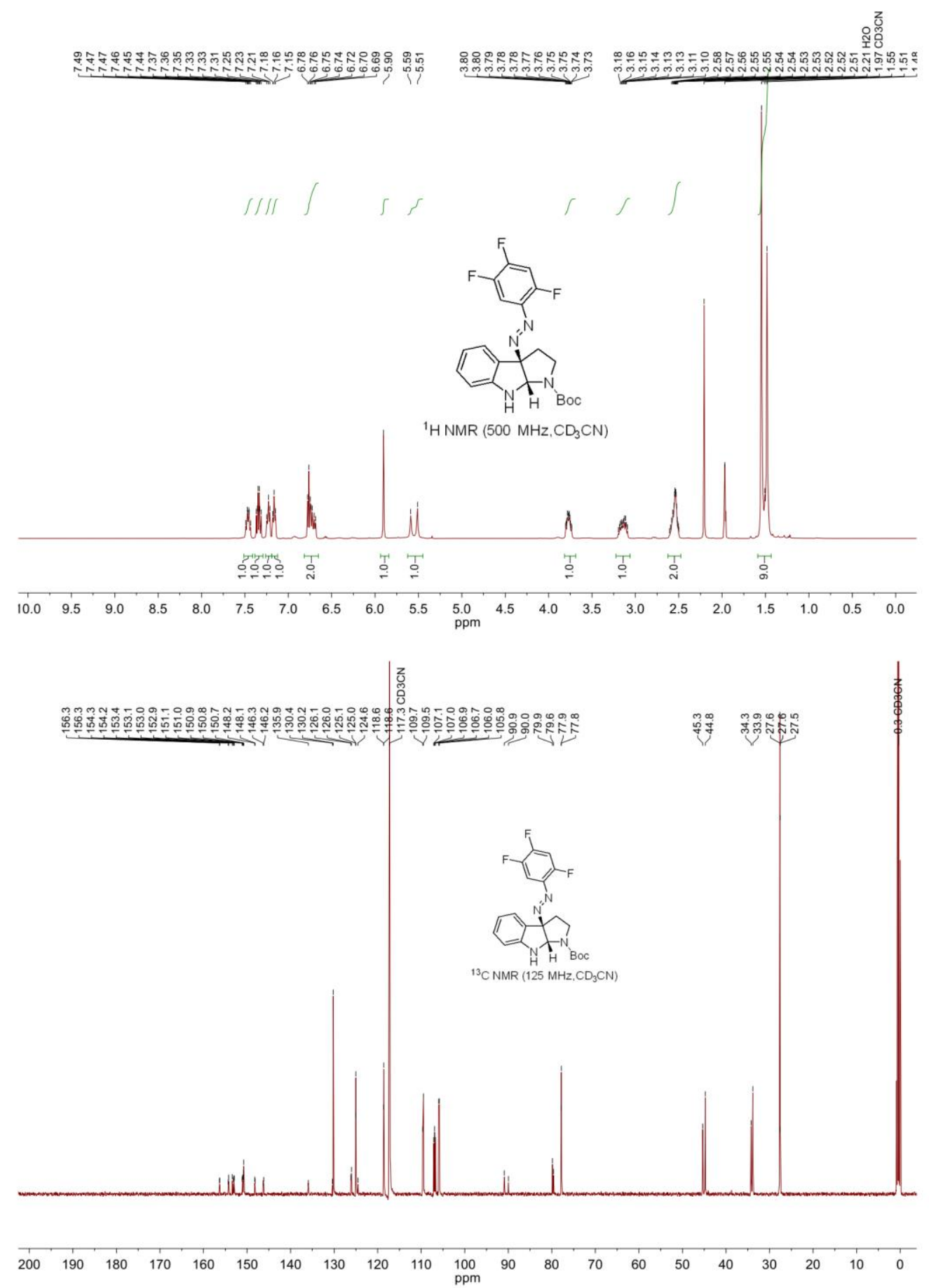


1-(tert-Butyl)-2-methyl $\left(2 R^{*}, 3 \mathrm{a} R^{*}, 8 \mathrm{a} S *\right)-3 \mathrm{a}-((E)-(3,5-$

bis(trifluo ro methyl) phenyl)diazeny l)-3,3a,8,8a-te trahy dropy rrolo $[2,3-b]$ indole-1,2(2H)dicarboxylate $(\mathrm{S4})$
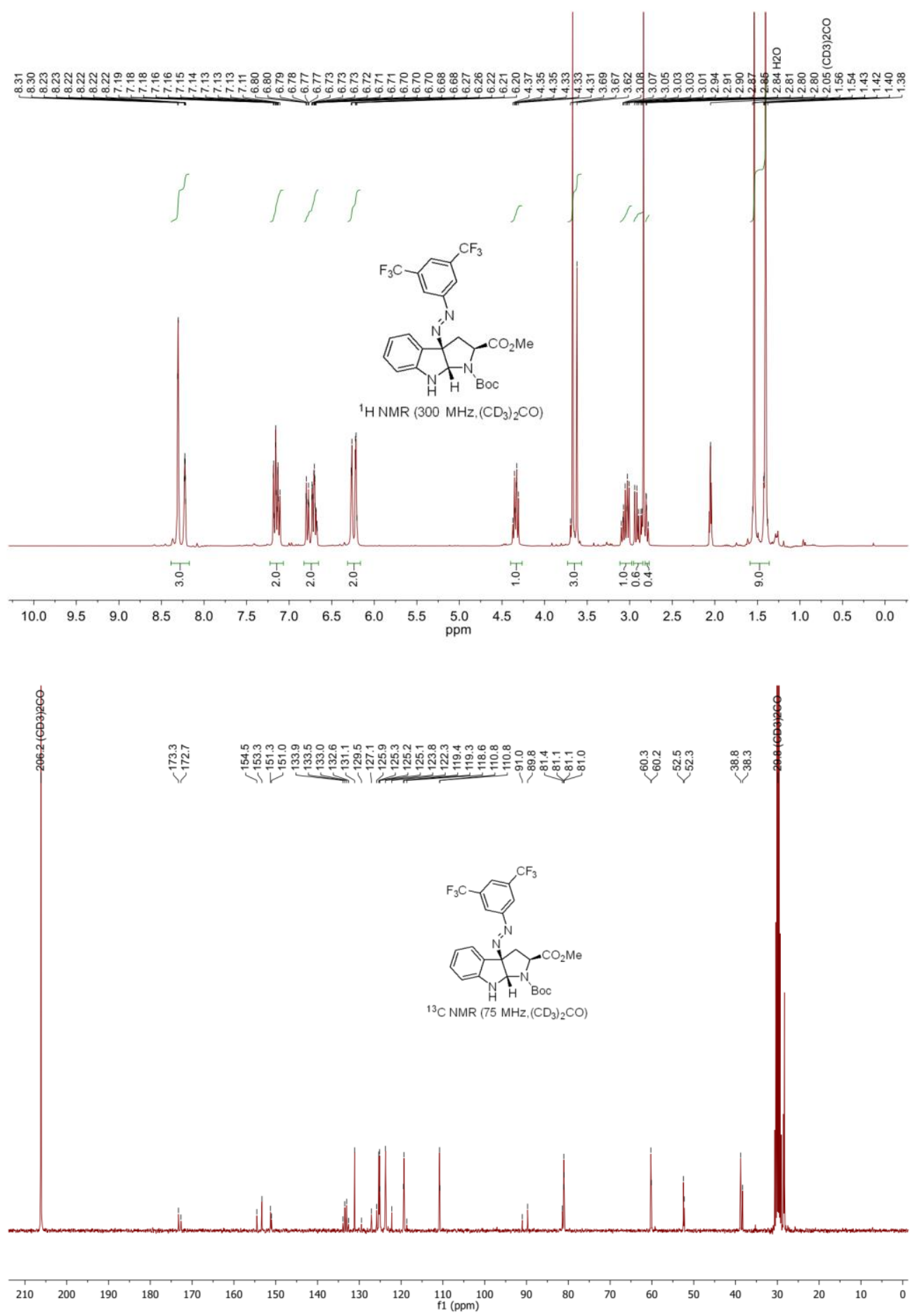
$\left(3 \mathrm{a} R^{*}, 8 \mathrm{a} S^{*}\right)-3 \mathrm{a}-((E)$-Phenyldiazenyl)-1-tosyl-1,2,3,3a,8,8a-he xahy dropy rrolo [2,3$b$ ]indole (S5)

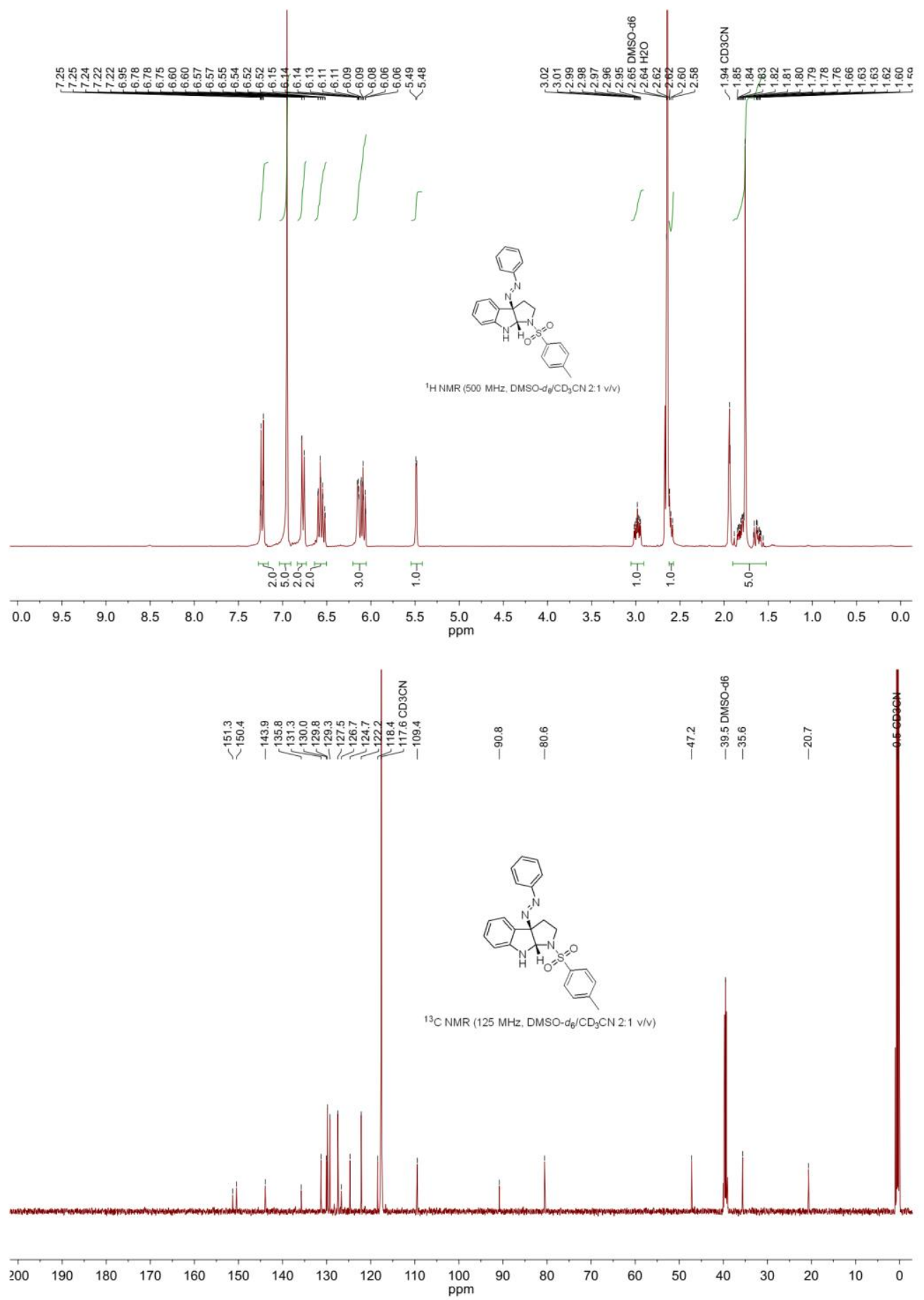


$(3 \mathrm{a} R *, 8 \mathrm{a} S *)-3 \mathrm{a}-((E)-(4-M e t h o x y-2-n i t r o p h e n y l)$ diazenyl) -3,3a,8,8a-tetrahy dro-2Hfuro $[2,3-b]$ indole (S6)
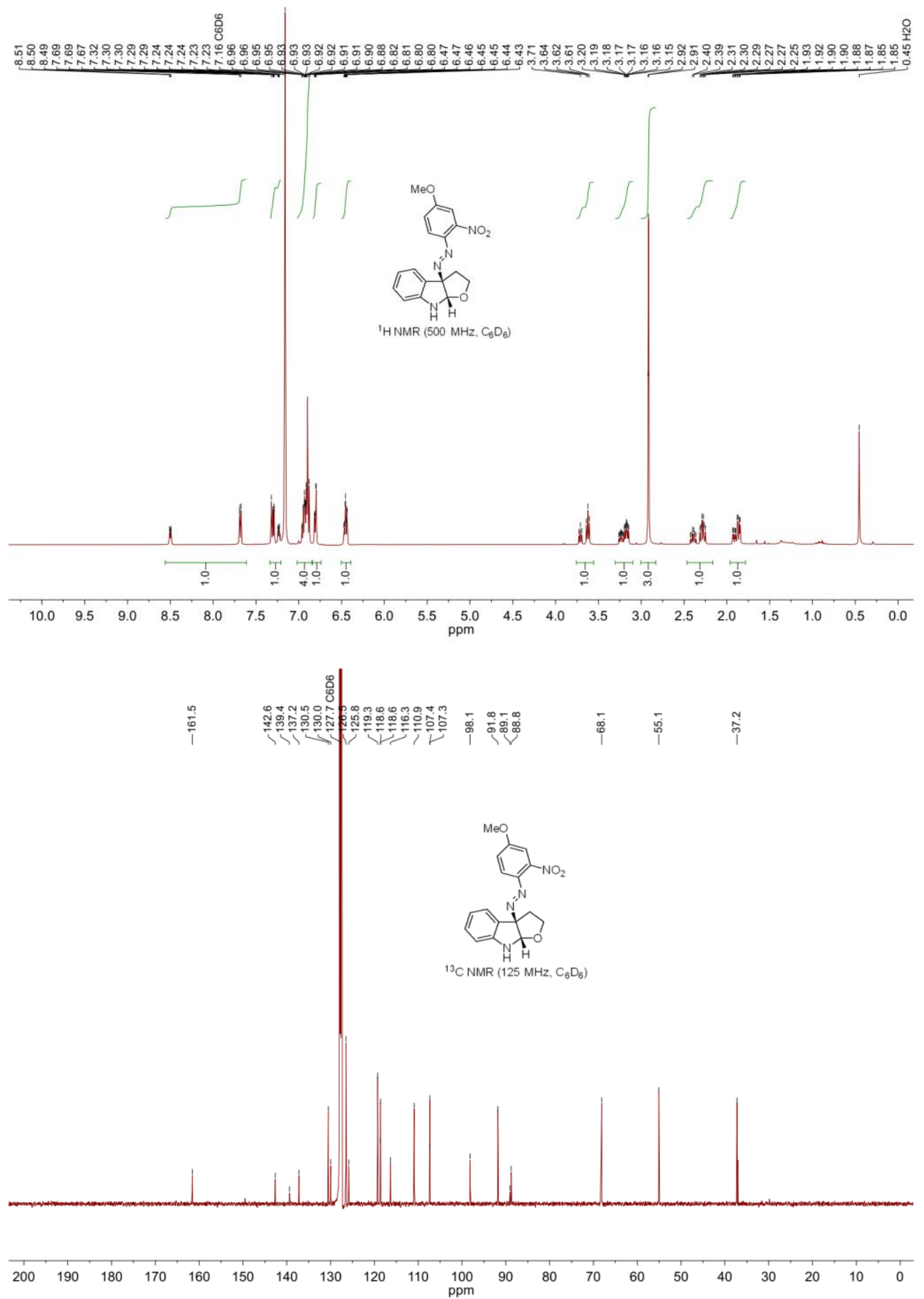
$\left(3 \mathrm{a} R^{*}, 8 \mathrm{a} S^{*}\right)-3 \mathrm{a}-((E)-(4-I o d o p h e n y l) d i a z e n y l)-1-t o s y l-1,2,3,3 \mathrm{a}, 8,8 \mathrm{a}-$ hexahydropyrrolo[2,3-b]indole (S7)
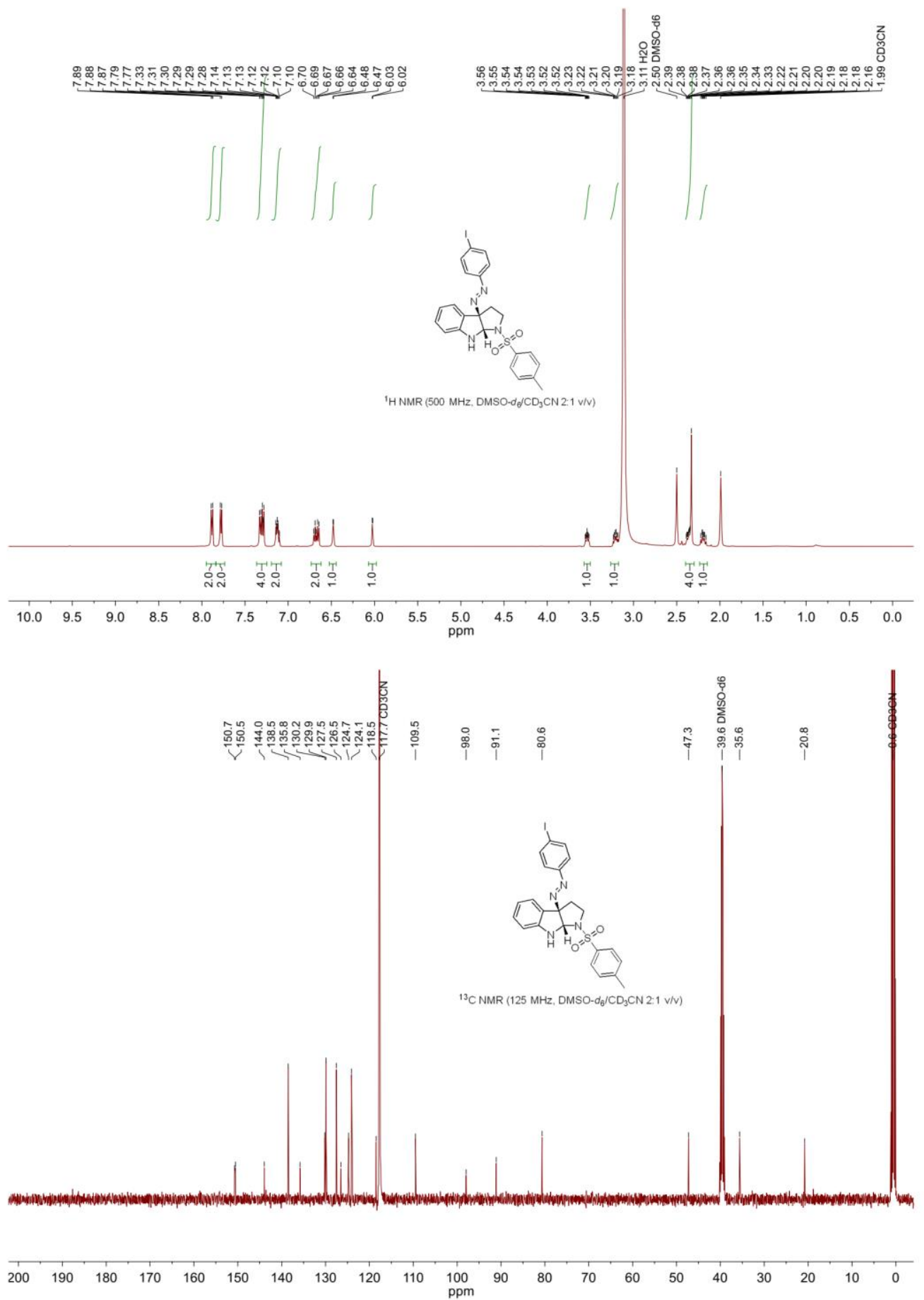
tert-Butyl (3a $\left.R^{*}, 8 \mathrm{a} S *\right)-3 \mathrm{a}-((\mathrm{E})-(4-m e t h o x y-2-n i t r o p h e n y l)$ diazenyl)-3,3a,8,8atetrahydropy rrolo $[2,3-b]$ indole-1 $(2 H)$-carboxylate $(\mathrm{S8})$

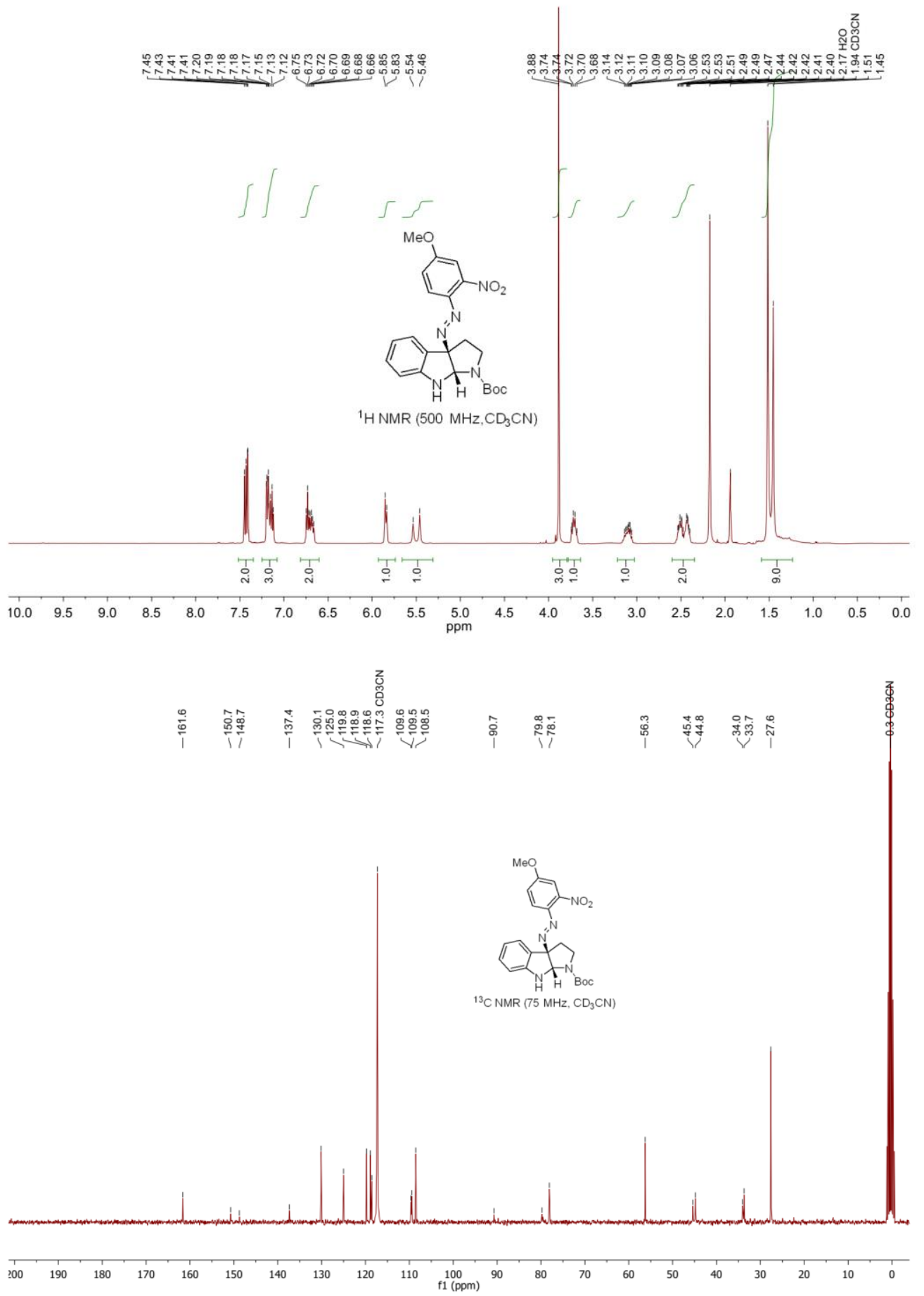


1-((3a $\left.R^{*}, 8 \mathrm{a} S^{*}\right)-3 \mathrm{a}-((E)$-Phenyldiazeny $)-3,3 \mathrm{a}, 8,8 \mathrm{a}-$ te trahy dropy $\operatorname{rrolo}[2,3-b]$ indol-1(2H)yl)ethan-1-one (S9)
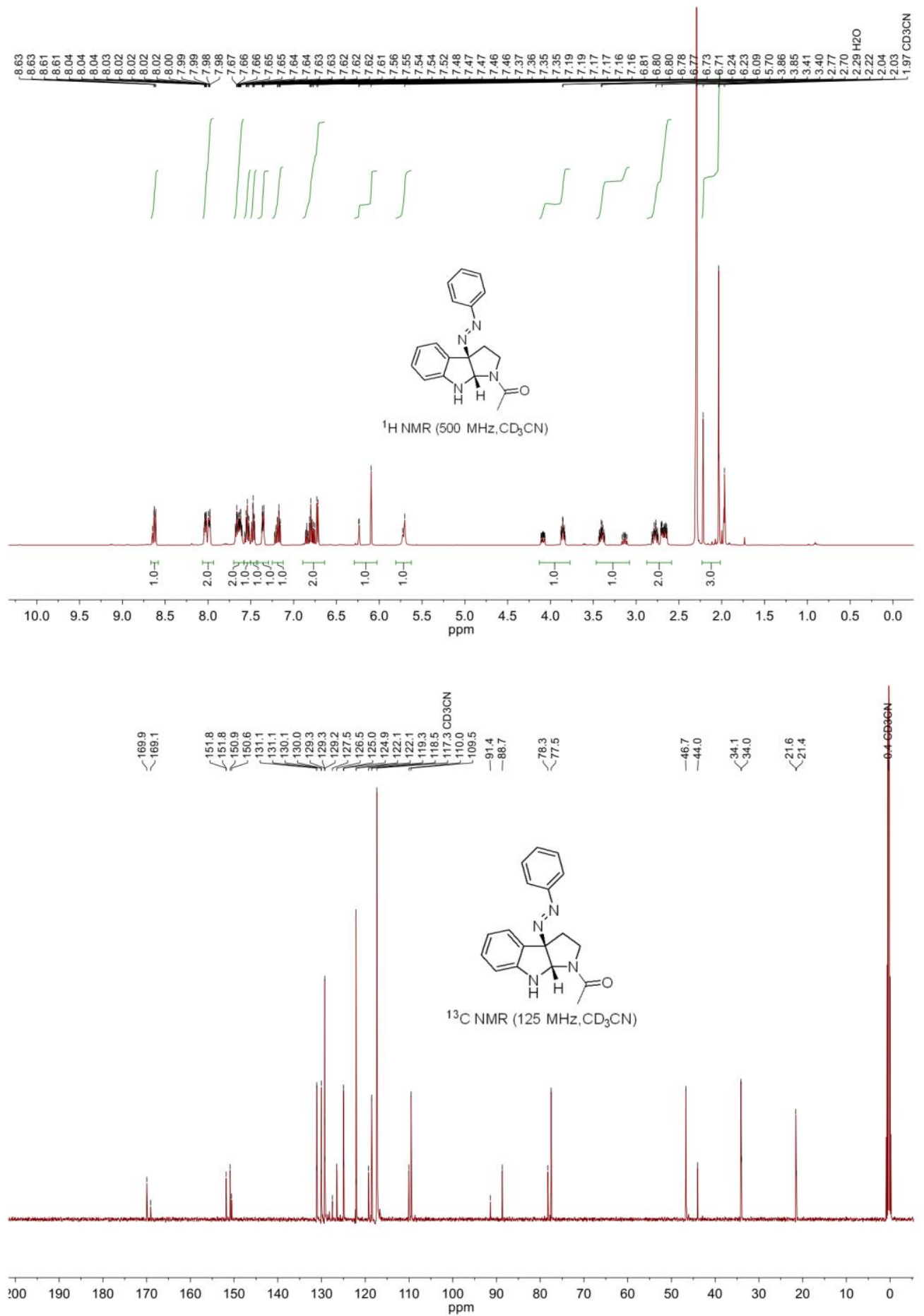
Benzyl (3a $\left.R^{*}, 8 \mathrm{a} S *\right)-3 \mathrm{a}-((E)-(3,5-b i s($ trifluo romethyl)phenyl)diazenyl)-3,3a,8,8atetrahydropy rrolo $[2,3-b]$ indole-1 $(2 H)$-carboxy late $(\mathrm{S10})$
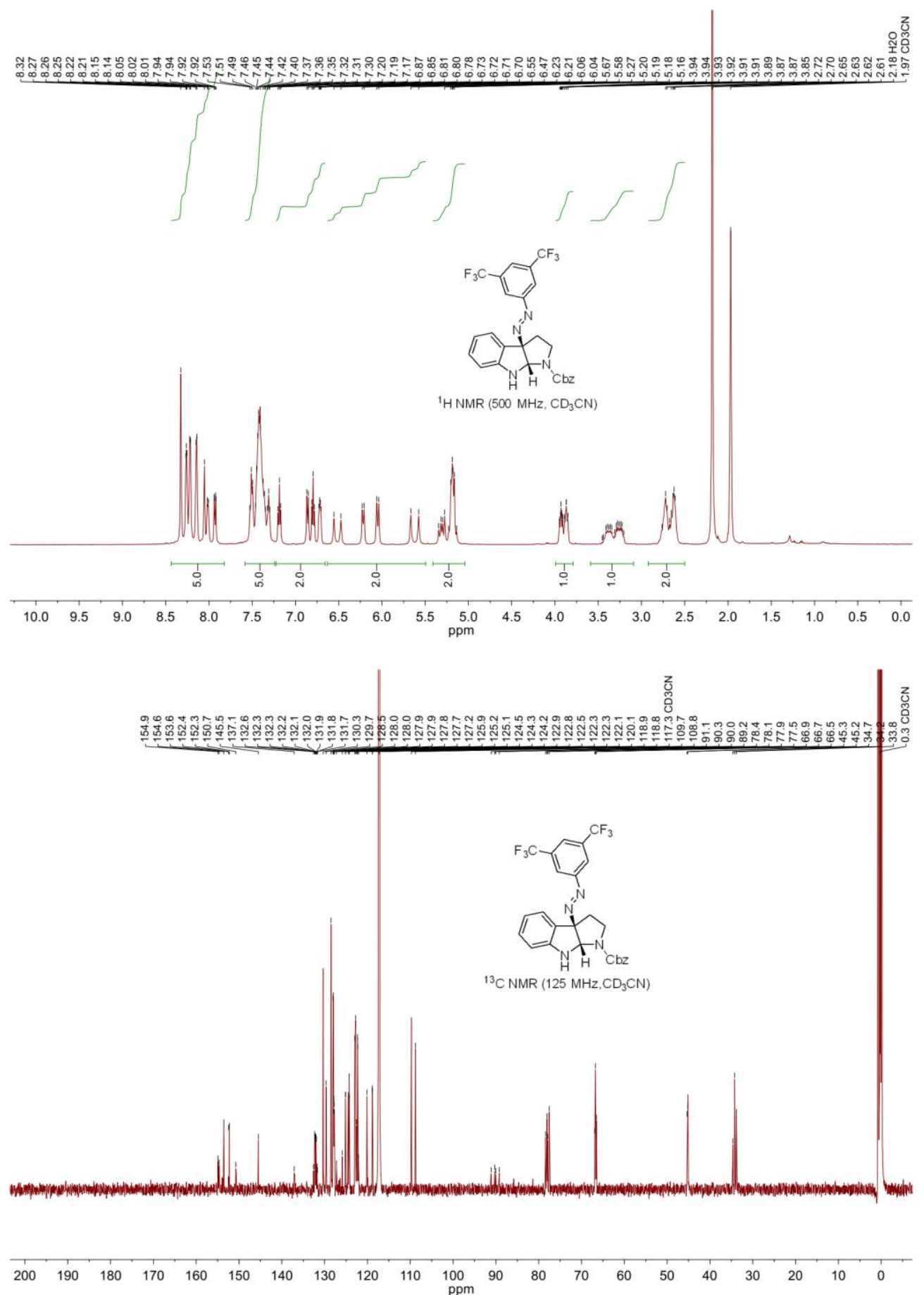
Benzyl (3a $\left.R *, 8 a S^{*}\right)-3 a-((E)-(2,4,5$-trifluorophenyl)diazenyl)-3,3a,8,8atetrahydropy rrolo $[2,3-b]$ indole-1 $(2 H)$-carboxy late (S11)
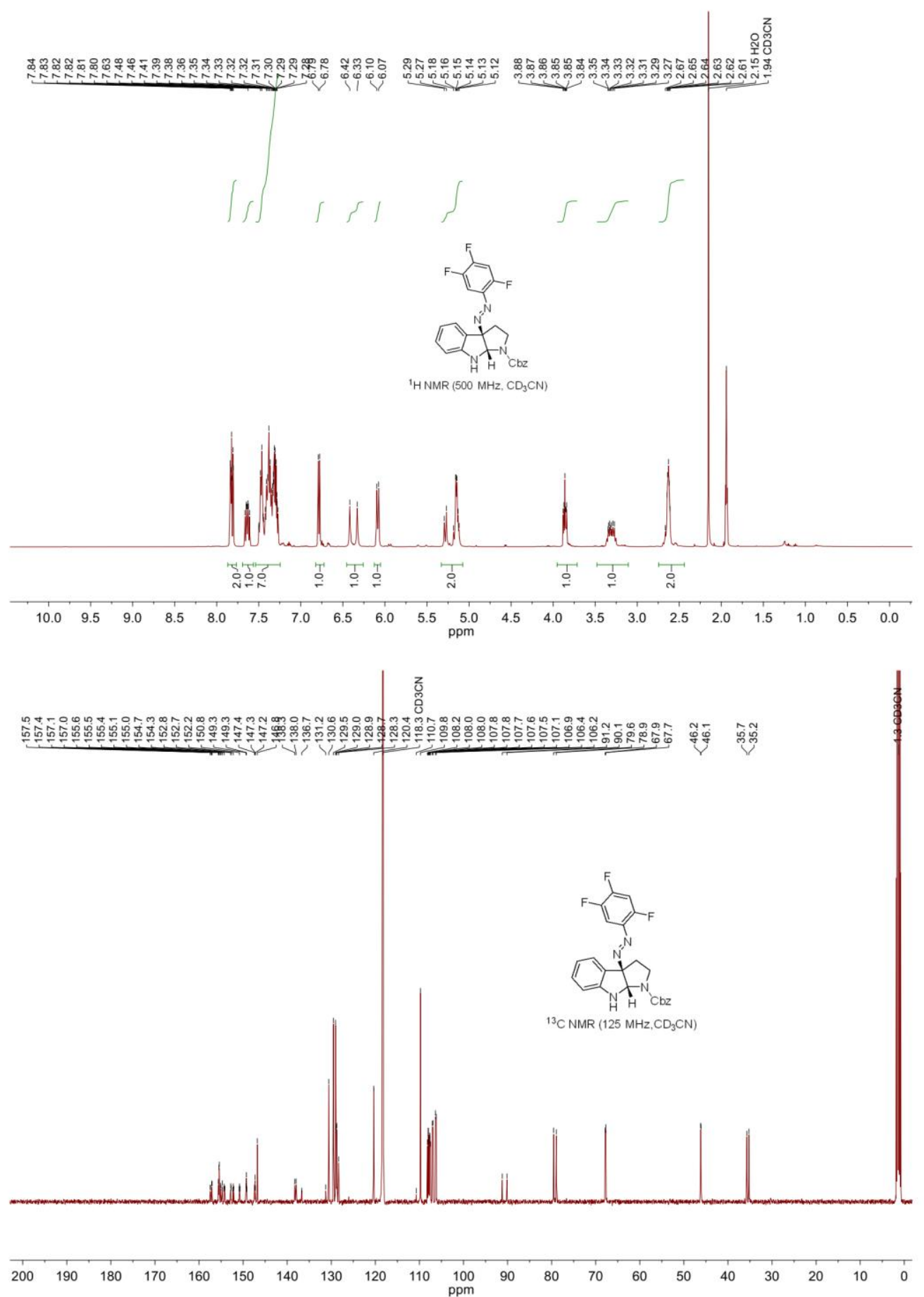
Benzyl (3a $\left.R^{*}, 8 \mathrm{a} S^{*}\right)-3 \mathrm{a}-((E)-(4-i o d o p h e n y l)$ diazenyl)-3,3a,8,8a-tetrahydropy rolo[2,3b]indole-1(2H)-carboxylate (S12)
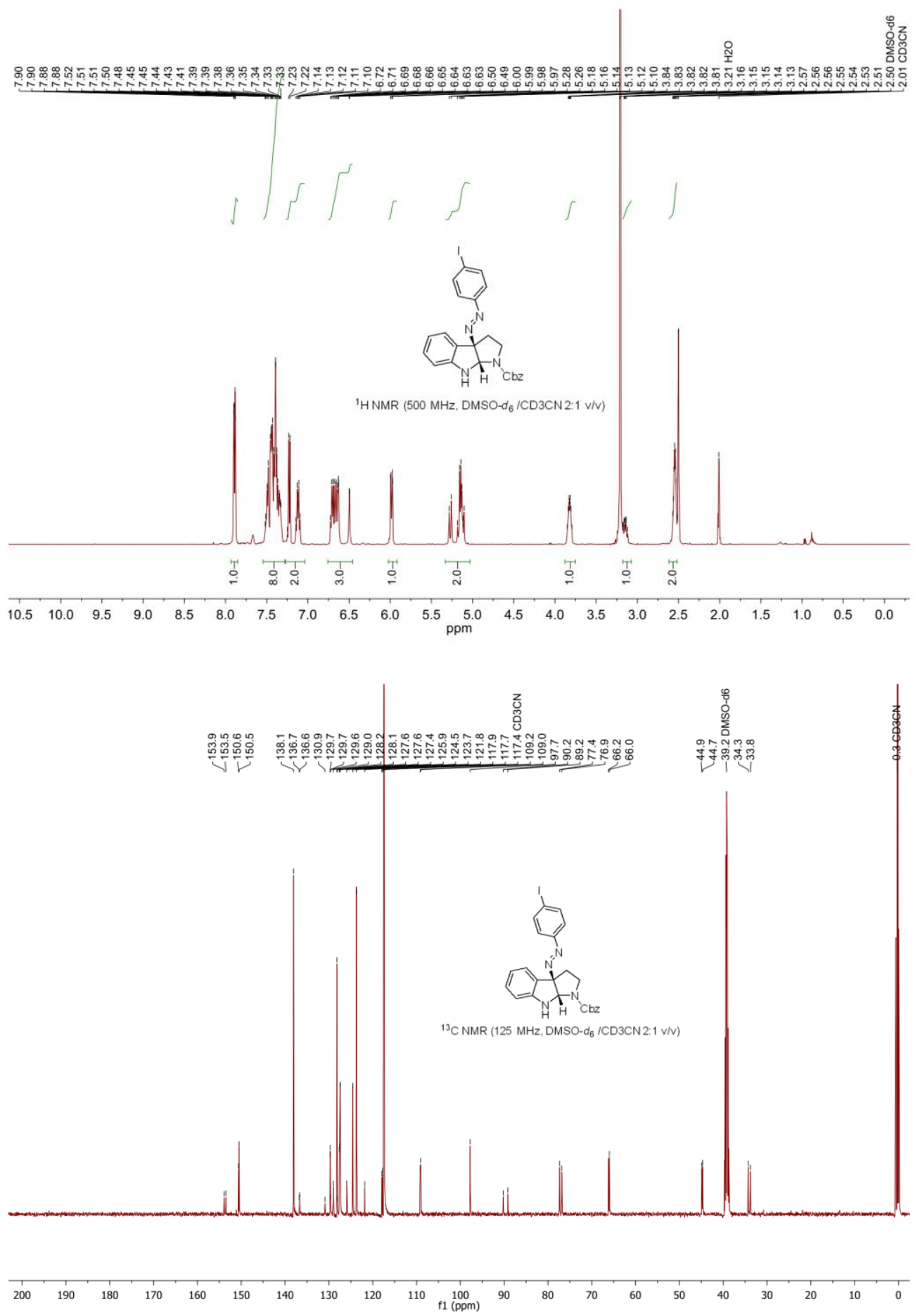
$(3 \mathrm{a} R *, 8 \mathrm{a} S *)-1-B e n z y l-3 a-((E)-$ phenyldiazenyl) $)-3,3 \mathrm{a}, 8,8 \mathrm{a}-$-te tra hy dropy rrolo $[2,3-$

b]indol-2(1H)-one (1)
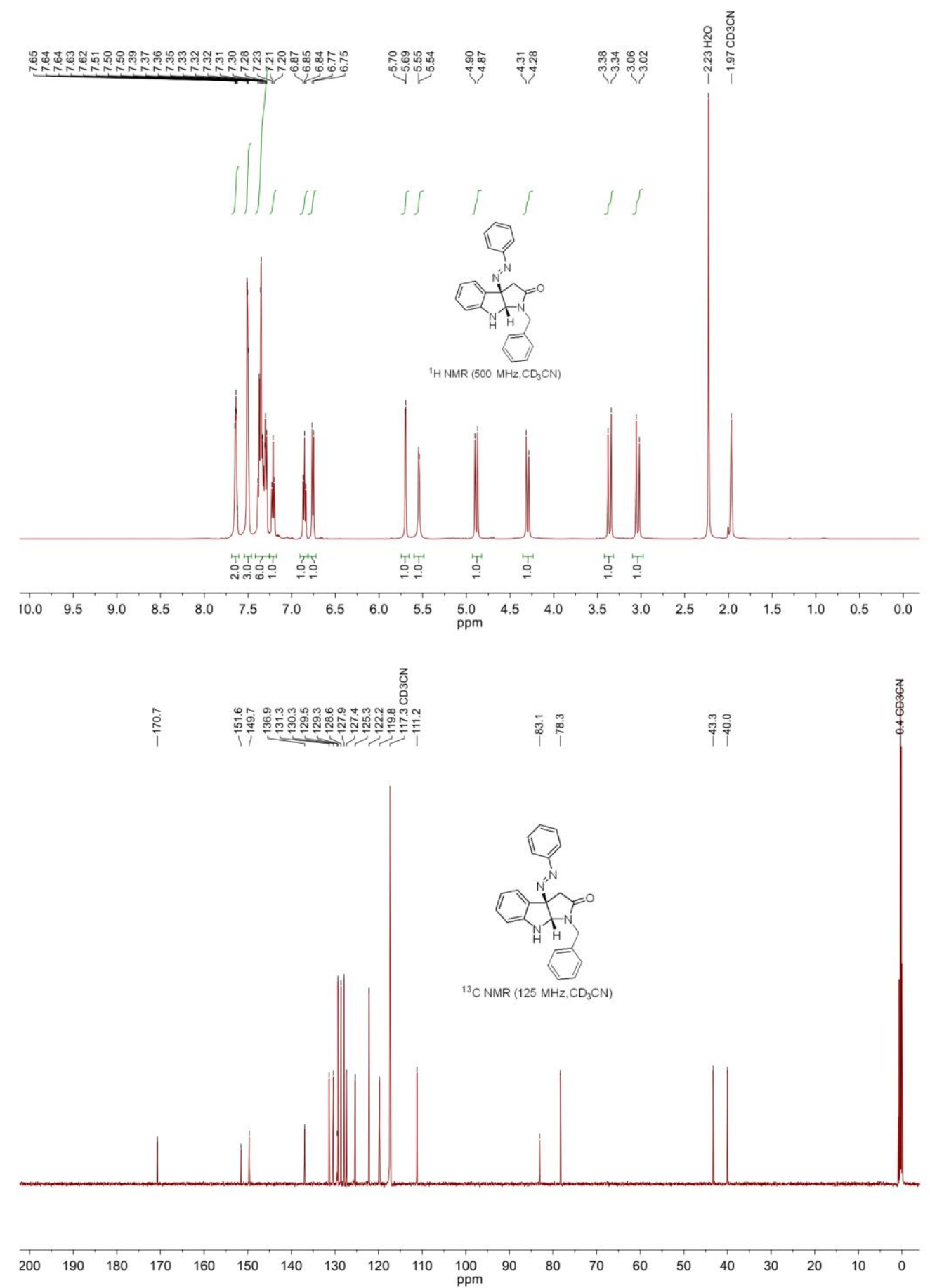
((3a $\left.R^{*}, 8 \mathrm{a} S^{*}\right)-3 \mathrm{a}-((E)-(3,5-B i s(t r i f l u o r o m e t h y l) p h e n y l) d i a z e n y l)-5-c h l o r o-3,3 a, 8,8 \mathrm{a}-$ tetrahydropy rrolo $[2,3-b]$ indol-1(2H)-yl)(phenyl)methanone (2)
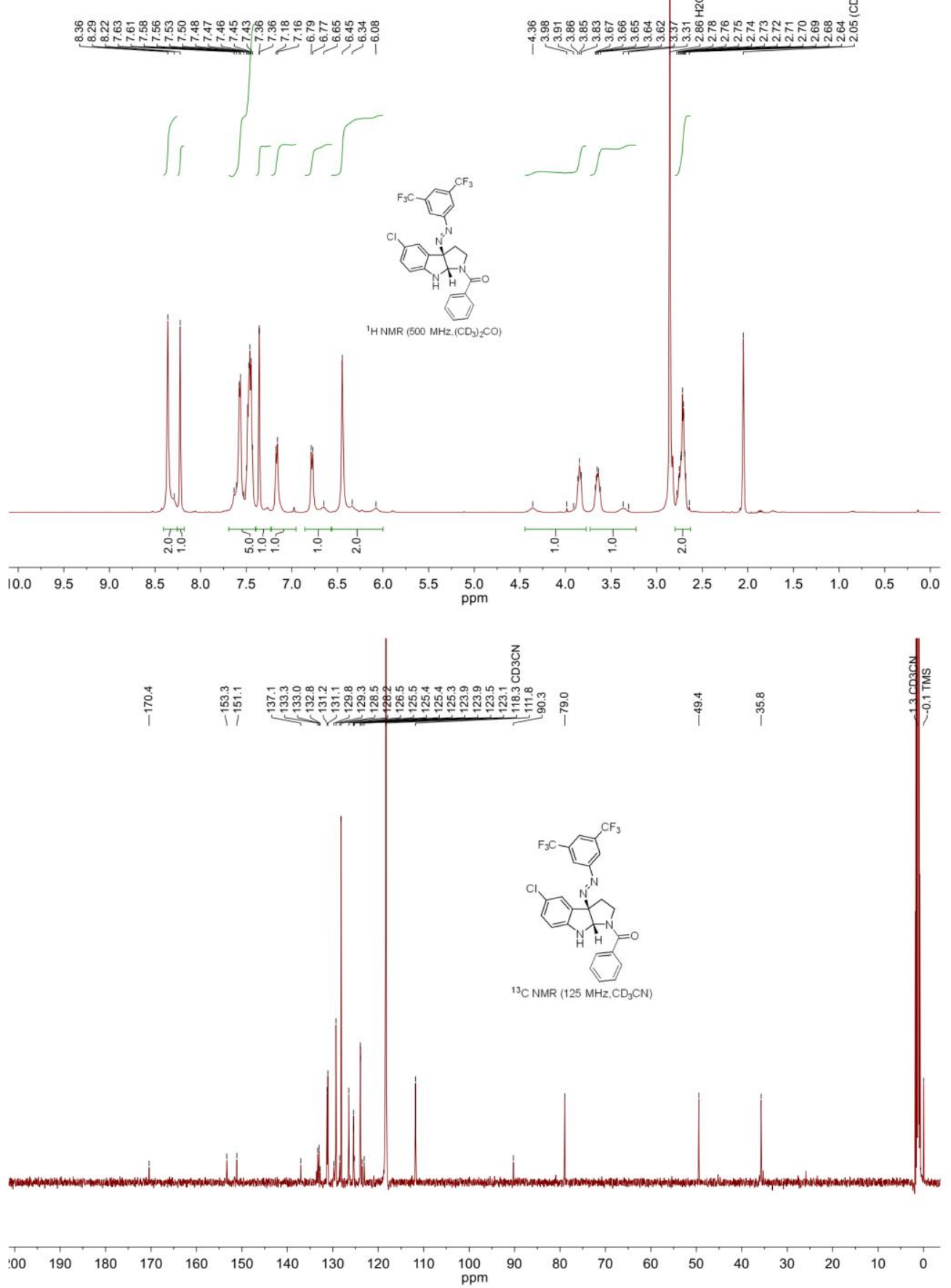
1-((3a $R *, 8 \mathrm{a} S *)-3 \mathrm{a}-((E)-(3,5-B$ is (trifluo romethyl)phenyl)diazenyl)-5-me thoxy -

3,3a,8,8a-tetrahydropy rrolo[2,3-b]indol-1(2H)-yl)ethan-1-one (3)
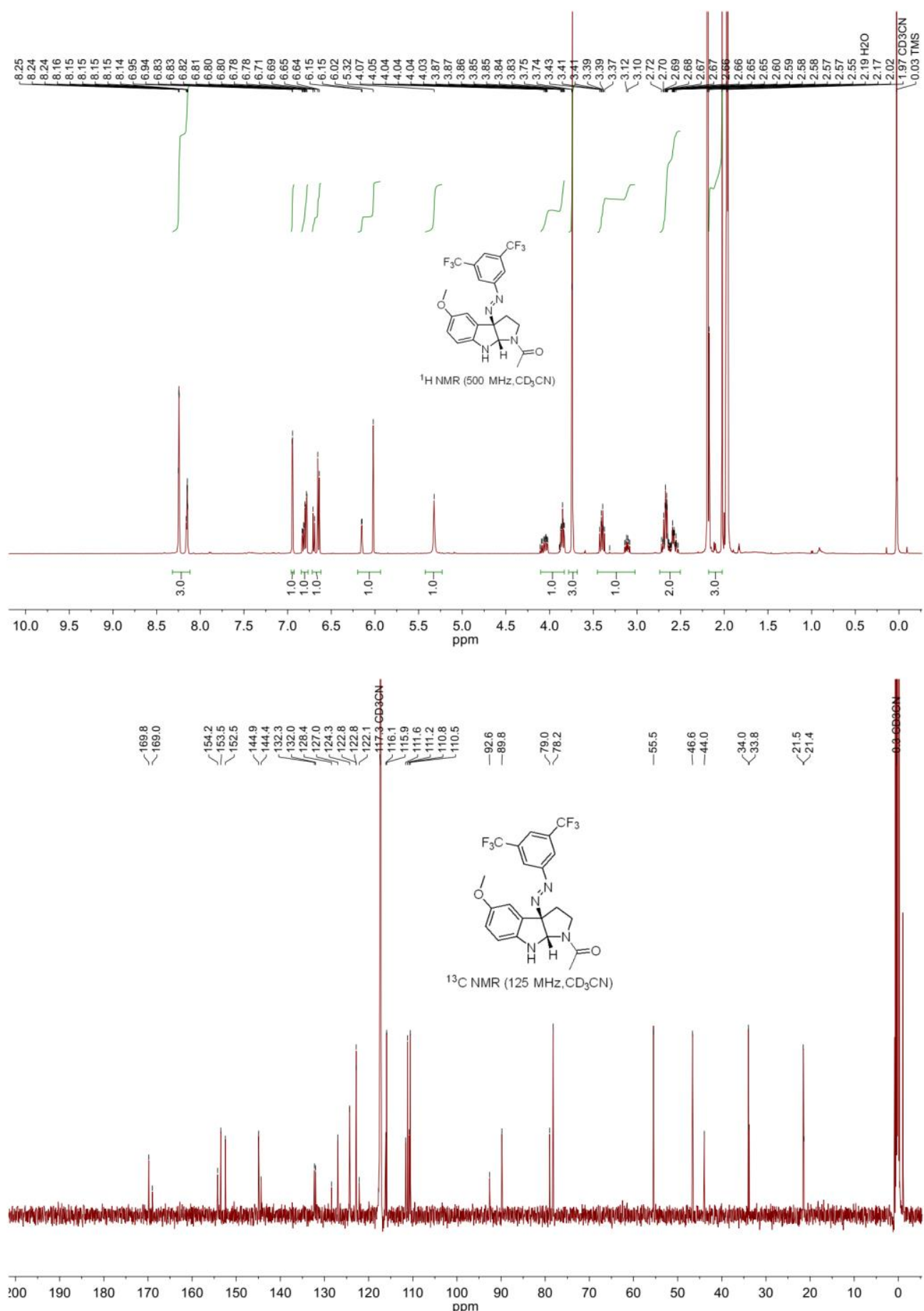
$\left(3 \mathrm{a} R *, 8 \mathrm{a} S^{*}\right)-3 \mathrm{a}-((E)-N a p h t h a l e n-1$-yldiazenyl)-1-tosyl-1,2,3,3a,8,8ahexahydropyrrolo[2,3-b]indole (4)
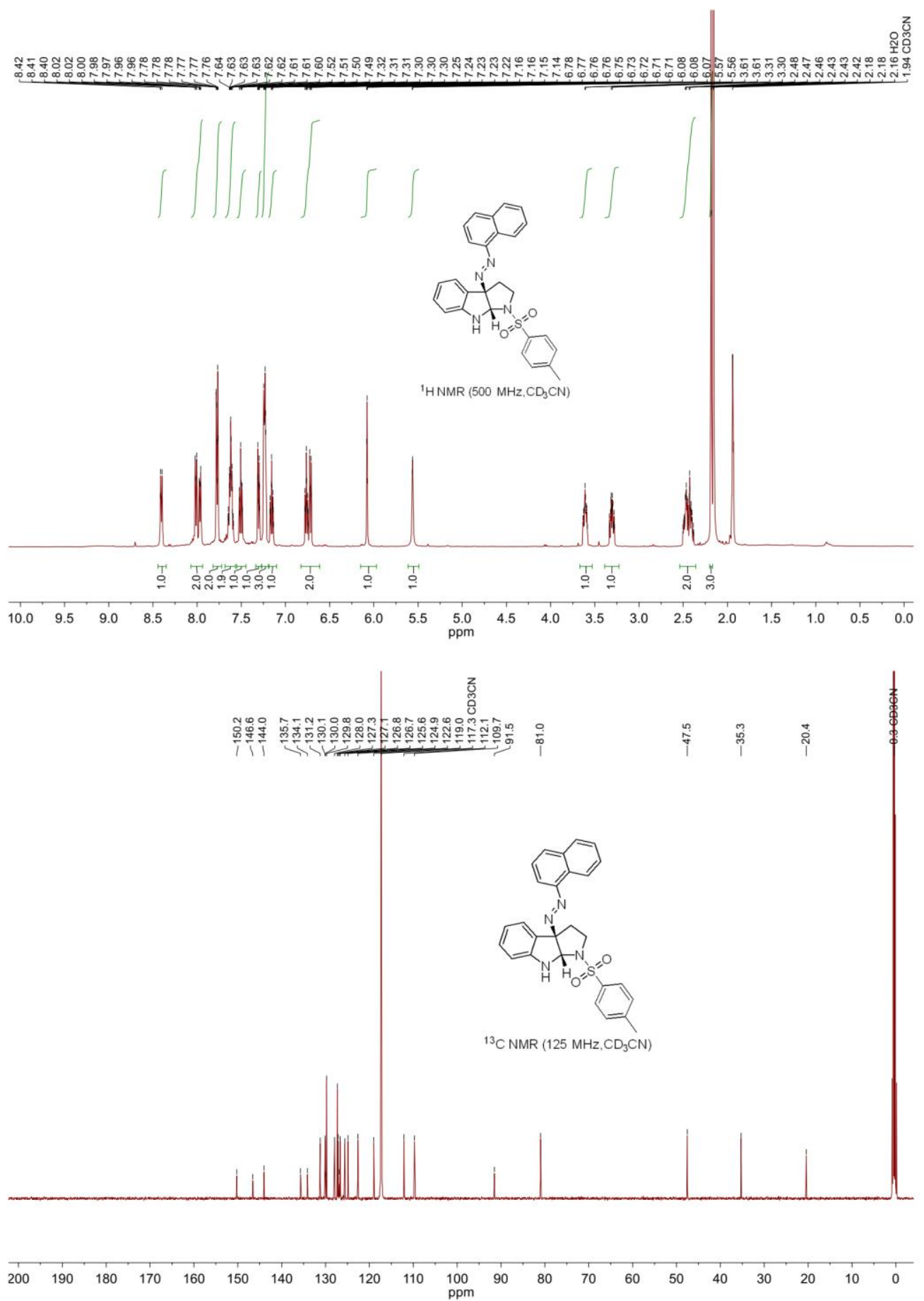


\section{REFERENCES}

1. Hess, B.; Bekker, H.; Berendsen, H. J. C.; Fraaije, J. G. E. M., LINCS: A linear constraint solver for molecular simulations. J Comput Chem 1997, 18, 1463-1472.

2. Miyamoto, S.; Kollman, P. A., Settle: an analytical version of the SHAKE and RATTLE algorithm for rigid water models. J Comput Chem 1992, 13, 952-962.

3. Berendsen, H. J. C.; Postma, J. P. M.; van Gunsteren, W. F.; Dinola, A.; Haak, J. R., Molecular dynamics with coupling to an external bath. J Chem Phys 1984, 81, 3684-3690.

4. Verlet, L., Computer "experiments" on classical fluids I. Thermodynamical properties of Lennard-Jones molecules. Phys Rev 1967, 159, 98-103.

5. van Gunsteren, W. F.; Berendsen, H. J. C., A leap-frog algorithm for stochastic dynamics. Mol Simul 1988, 1, 173-185.

6. Parrinello, M.; Rahman, A., Polymorphic transitions in single crystals: A new molecular dynamics method. J Appl Phys. 1981, 52 (12), 7182-90.

7. Essmann, U.; Perera, L.; Berkowitz, M. L.; Darden, T.; Lee, H.; Pedersen, L. G., A smooth Particle Mesh Ewald method. J Chem Phys 1995, 103, 8577-8592.

8. van der Spoel, D.; Lindahl, E.; Hess, B.; van Buuren, A. R.; Apol, E.; Meulenhoff, P. J.; Tieleman, D. P.; Sijbers, A. L. T. M.; Feenstra, K. A.; van Drunenand, R.; Berendsen, H. J. C., GROMACS UserManual. Royal Institute of Technology and Uppsala University: Sweden, 2013. 